\title{
Multimodal Method for Coseismic Landslide Hazard Assessment
}

\author{
Alex Grant ${ }^{1 *}$, Joseph Wartman ${ }^{1}$, Grace Abou-Jaoude ${ }^{2}$
}

1. University of Washington, Seattle, Washington, USA

2. Lebanese American University, Civil Engineering, 408 Bassil Bldg., Byblos, Lebanon

* Corresponding author, University of Washington, Dept. of Civil and Environmental Engineering, 201 More Hall, Seattle WA 98195-2700, USA, agrant3@uw.edu

Regional-scale coseismic landslide hazard assessments have traditionally been based on infiniteslope analyses, considering only a single mode of failure. Inventories and landslide reconnaissance work have shown a diverse range of coseismic landslide modes with significantly different consequences of failure. This paper presents a multimodal approach for regional-scale coseismic landslide hazard assessment. Through a two-step procedure, the multimodal method explicitly accounts for four general landslide types commonly observed during earthquakes: rock-slope failures, disrupted soil slides, coherent rotational slides, and lateral spreads. First, the susceptibility to each landslide mode is evaluated based on topography. Second, coseismic landslide hazards are assessed using mode-specific geotechnical models. A trial multimodal landslide assessment is presented for the seismically active country of Lebanon. Results show that the computed coseismic landslide hazard closely matches field-verified slope activity across different regions of the country exhibiting a range of failure modes. These results qualitatively demonstrate the efficacy of the procedure and suggest that multimodal coseismic landslide hazard analysis is especially well-suited for regions with varying terrain and where landslide inventories are not available.

\section{Keywords: landslide, hazard, coseismic, modes of failure}




\section{Introduction}

Earthquake-induced, or coseismic, landslides occur in great number during moderate to large (M>5) earthquakes (Keefer, 2013; Rodríguez et al., 1999). These landslides typically occur across regions spanning hundreds to thousands of square kilometers (Keefer, 1984). The widespread geographic distribution of coseismic landslides makes them, by definition, regionalscale events. For this reason, coseismic landslide hazards are usually assessed using regionalscale (i.e., 1:250,000 - 1:25,000, Corominas et al., 2014) forecasting models. These models are valuable because they indicate the spatial distribution of coseismic landslides and additionally have the potential to capture seismic performance and propagation of risk across a region. This is especially important when considering the effects of slope failures on geographically distributed critical infrastructure systems, which are highly vulnerable to coseismic landslides (e.g. Wartman et al., 2003).

Regional-scale coseismic landslide hazard assessments are typically based on infinite-slope analyses (e.g. Wieczorek et al., 1985; Khazai and Sitar, 2000; Jibson et al., 2000; Saygili and Rathje, 2008), which theoretically limit their applicability to shallow landslides (Corominas et al., 2014). While infinite-slope based models have been shown to perform adequately for events where landslides primarily consist of shallow disrupted soil slides (e.g. the 1994 Northridge earthquake, Dreyfus et al., 2013), post-earthquake field investigations of other earthquakes reveal a diverse styles of coseismic landslides including rock-slope failures, rotational slumps, and lateral spreads (e.g. Keefer, 1984; Rodríguez et al., 1999; Sitar and Khazai, 2001; Bommer and Rodríguez, 2002; Keefer, 2002; Dai et al., 2011; Wartman et al., 2013). Ideally, landslide hazard assessments should capture the full range of coseismic failure modes. 
In this paper, we present a regional-scale coseismic landslide hazard assessment method that explicitly accounts for different modes of failure. This multimodal method considers four general modes (or types) of landslides commonly observed during earthquakes: (1) rock-slope failures, (2) disrupted soil slides, (3) coherent rotational slides, and (4) lateral spreads. Application of the multimodal method follows a two-step procedure: first, susceptibility to each landslide mode is evaluated based on topography; then, coseismic landslide hazards are assessed using modespecific geotechnical models. We developed the multimodal approach for regions where inventories of coseismic landslides are incomplete or otherwise not available. In such regions, it is often possible to estimate geologic strength parameters and acquire digital elevation model (DEM) data, but impractical to apply regression-based assessment procedures trained on coseismic landslide databases from a specific geographic area (e.g. Lee et al., 2008).

We conduct a trial multimodal landslide hazard assessment for Lebanon, which has good quality geologic and topographic data. The discovery and mapping of the offshore Mount Lebanon Thrust Fault (Elias et al., 2007), linked to a historic $\sim$ M7.2 earthquake, has significantly raised the seismic hazard in Lebanon (Huijer 2010; Huijer et al., 2011) and suggests the potential for coseismic landslides across the country. Results from our trial application show that the computed coseismic landslide hazard closely matches field-verified slope activity across different regions of the country exhibiting widely varied terrains. The results demonstrate the efficacy of the procedure and suggest that multimodal coseismic landslide hazard analysis is well suited for regions of varied terrain where landslide inventories are not available. A unique benefit of the multimodal method is that it provides a spatial disaggregation of coseismic 
landslide mode across a region, which offers a cursory assessment of risk since each landslide failure mode will have different impacts on human populations and different consequences for infrastructure systems and the built environment.

\subsection{Coseismic Landslide Types and Consequences}

Keefer (1984) identified fourteen commonly occurring coseismic landslide modes of failure, which were simplified and refined in later work to three main categories: disrupted slides, coherent landslides, and lateral spreads and flows (Keefer, 1999). This range of coseismic failure modes has been reported in many post-event landslide investigations. For example, Keefer (2000) mapped $~ 1,300$ coseismic landslides within a $2,000 \mathrm{~km}^{2}$ zone that was highly impacted by the 1989 M6.9 Loma Prieta, California earthquake. Keefer (2000) observed that while most landslides were disrupted but that a considerable fraction (26\%) classified as coherent failures. Similarly, Khazai and Sitar (2004) found a majority of the landslides initiated by the 1999 M7.6 Chi-Chi, Taiwan earthquake to be disrupted failures, with coherent (11\%) and "other" (4\%) types of landslides also being significant (lateral spreads were omitted from the Loma Prieta and Chi-Chi datasets.) Wartman et al. (2013) mapped coseismic landslides triggered by the 2011 M9.0 Tohoku earthquake across a $28,000 \mathrm{~km}^{2}$ region and found most landslides to be disrupted (63\%), with a lesser but significant fraction to be lateral spreads (34\%) and coherent failures (3\%). However, taken in the context of "sediment mobilization" or landslide erosion volume, lateral spreads were the dominant mode of coseismic landslides (Wartman et al., 2013). Unlike disrupted failures, lateral spreads are not captured by traditional infinite-slope based landslide hazard analyses. 
Coseismic landslide failure modes are each associated with unique consequences of failure (e.g. Wartman et al. 2013; Keefer, 2013). For example, during the 2010-2011 Canterbury, New Zealand earthquake sequence, widespread liquefaction and associated lateral spreading resulted in significant damage to buildings and infrastructure systems (economic losses of $\sim$ \$15B NZD, Cubrinovski et al., 2014) but did not cause human losses. In contrast, rock-slope failures, which occurred in many locations in the Christchurch region, resulted in both highly localized damage and significant loss-of-life (Massey et al., 2012).

\section{Multimodal Model Development}

The multimodal method was developed to assess susceptibility to four common types of landslides and to compute the mode-specific coseismic landslide hazard on a regional scale. Topographic slope was adopted as an indicator to determine terrain susceptible to landslides, and where indicated, the landslide mode(s) most likely to occur. A geospatially continuous modespecific model was used to compute potential coseismic displacements based on the local ground shaking intensity. The coseismic landslide hazard was then defined based on computed displacements for all modes of failure following previous landslide studies (e.g. Godt et al., 2008; Jibson and Michael, 2009) and recognizing that coseismic displacement ultimately governs the serviceability of a slope after an earthquake (Kramer, 1996). The following sections describe the procedure used to identify landslide susceptibility and the geotechnical models used to assess each landslide mode.

\subsection{Types of Landslides}


Keefer (1984) studied 40 coseismic landslide datasets and found several types of landslides to be "very abundant" or "abundant," including rock falls and slides, disrupted soil slides, soil slumps, and soil lateral spreads. To capture this variation in coseismic landslide type, we focused on four fundamental modes of failure. Referencing Keefer's (1984) coseismic landslide classification system, these are: (1) rock slides and falls, (2) disrupted soil slides, (3) coherent rotational slides

(i.e., soil and rock slumps), and (4) lateral spreads (Fig. 1). Table 1 summarizes the landslide modes, as well their commonly observed characteristics and typical source zone slope inclinations. Figure 2 shows an example of each type of landslide. Other less common modes of failure, such as soil falls or earth flows, were omitted as they are unlikely to contribute significantly to the overall landslide hazard.

\subsubsection{Mode of Failure Susceptibility Zonation}

For many landslide susceptible regions in the world, detailed inventories are not available, thus preventing the use of region-specific statistical measures of future landslide susceptibility. However, previous studies and landslide reconnaissance investigations have identified clear relationships between mode of failure and slope of landslide source areas (e.g. Keefer, 1984; Keefer 2013). We adopted these findings to delineate the most likely coseismic mode(s) of failure within a study region within specific slope bounds. Lateral spread susceptibility was restricted to slopes of $0^{\circ}-6^{\circ}$ based on Bartlett and Youd (1995) who found that liquefaction in slopes $>6^{\circ}$ would likely produce flow slides, which are not considered in this work. Slopes from $15^{\circ}-50^{\circ}$ are assumed to be susceptible to disrupted soil sliding based on observations of Keefer (1984) and the assumption that slopes steeper than $50^{\circ}$ exhibit rock-like behavior. 
Terrain susceptible to potentially significant coherent rotational sliding movements was limited to slopes from $20^{\circ}-35^{\circ}$. While coseismic rock and soil rotational slides failures have been observed in gentler slopes in past events, we constrained failures based on our assumed slip surface geometry (section 2.2.3) and an assumed transition from deep to shallow soil and rock failures above $35^{\circ}$ slopes. Rock-slope failures were considered for only slopes steeper than $35^{\circ}$ based on the observations of Toppe (1987), Lee (2013), and Keefer (2013).

Slopes from $6^{\circ}-15^{\circ}$ were assumed to have low susceptibility to our considered coseismic landslide modes. Low susceptibility terrain was assigned to reflect the relative scarcity of coseismic landslides in modest slopes (below 20 ${ }^{\circ}$ ) in datasets with respect to steeper slopes (e.g. Northridge, Harp and Jibson, 1996; Wenchuan, Dai et al., 2011; multiple other events, Meunier et al., 2007) and to eliminate the need to characterize the geotechnical properties of soil and rock for regions unlikely to experience significant coseismic deformation. The upper bound of $15^{\circ}$ was selected to be consistent with the observations of Keefer $(1984,2013)$ that shallow disrupted soil slides, which often dominate coseismic landslide occurrence, may trigger in slopes as shallow as $15^{\circ}$. Low susceptibility terrain was not considered in our later analyses based on the assumption that they would negligibly contribute to the overall coseismic hazard.

\subsection{Mode-Specific Coseismic Hazard Assessment}

\subsubsection{Rock-slope Failures}

We modeled rock-slope failures-including the block slides and falls frequently observed in earthquakes (e.g. Massey et al., 2012)-as Culmann wedge-like masses (Duncan et al., 2014). This methodology captures both the brittle behavior typically associated with rock-slope failures 
and the planar nature of structural controls (i.e., discontinuities) common in rock masses. To constrain individual block geometries in a geographic information system (GIS) environment, local relief $(H)$ was calculated for each susceptible pixel location based on a moving window analysis. This window size should be selected to best capture the major hillslope features within a study area. Window sizes that do not fully capture hillslopes will underestimate hazard, while overly broad windows will provide overestimates of coseismic hazards. Rock-slope failures were then assumed to potentially occur within the upper quarter of local relief based on observations from past earthquakes (Meunier et al., 2008; Massey et al., 2014). The static factor-of-safety $(F S)$ for was then computed for each pixel as:

$F S=\frac{2 \sin \beta}{\gamma h \sin (\beta-\alpha) \sin \alpha}+\frac{\tan \phi}{\tan \alpha}$

Equation 1

where $\beta$ is the slope angle [rad], $\phi$ and $c$ are the friction angle [rad] and cohesion [kPa] of the rock mass, $\alpha$ is the slope's critical angle given by: $\alpha=\left(\frac{\beta+\phi}{2}\right), h$ is the vertical height of the failure mass $[\mathrm{m}](h=0.25 H)$, and $\gamma$ is the unit weight of rock $\left(\mathrm{kN} / \mathrm{m}^{3}\right)$.

Static factors-of-safety were converted to yield acceleration values as (Newmark, 1965):

$k_{y}=(F S-1) g \sin \theta$

Equation 2

where $g$ is the acceleration of gravity $\left[\mathrm{m} / \mathrm{sec}^{2}\right]$, and $\theta$ is the failure plane angle, $\theta=\alpha$ for rockslope failures and $\theta=\beta$ for infinite slope conditions as described below. Coseismic displacements [cm] were then estimated using Jibson's (2007) sliding block displacement regression equation, which is a function of the yield acceleration $\left(k_{y}\right)$ and peak ground acceleration (PGA) [both computed in units of $g$ ]:

$\log D_{N}=0.215+\log \left[\left(1-\frac{k_{y}}{P G A}\right)^{2.341}\left(\frac{k_{y}}{P G A}\right)^{-1.438}\right]$ Equation 3

\subsubsection{Disrupted Soil Slides}


As in previous regional-scale coseismic landslide studies (e.g. Wieczorek et al., 1985; Jibson et al., 2000; Allstadt et al., 2013), the static factor-of-safety (FS) for shallow disrupted sliding was calculated assuming dry infinite slope-like failure conditions. Schmidt et al. (2001) found that root systems of vegetated hillslopes can provide a significant degree of "root cohesion" to the upper layer of regolith. To assess the potential contribution of root cohesion $\left(c_{r}\right)$ to coseismic slope resistance, we compared the Northridge earthquake inventory (Harp and Jibson, 1996) with pre-earthquake LANDSAT 5 satellite data of the region. We observed a clear relationship between the relative normalized difference vegetation index (NDVI) values and the intensity of coseismic landslides within terrain susceptible to disrupted slides (Fig. 3). Specifically, we found heavily vegetated sloping terrain $\left(20^{\circ}-50^{\circ}\right)$ to be virtually free of landslides $(1 \%$ of the mapped landslides occurred in the top decile [most vegetated] of relative NDVI values). In contrast, minimally vegetated sloping terrain (bottom half of relative NDVI values) accounted for the majority of landslides (73\%.) Accordingly, we modified the general infinite slope equation (Duncan et al., 2014, Fig. 1B) to include the contribution of root cohesion:

$F S=\frac{c+c_{r}}{\gamma \sin \beta}+\frac{\tan \phi}{\tan \beta}$ Equation 4 Here, $c_{r}$ is root cohesion $[\mathrm{kPa}], t$ is the thickness of failure mass $[\mathrm{m}], \gamma$ is the soil unit weight $\left[\mathrm{kN} / \mathrm{m}^{3}\right]$, and other terms are as defined for Equation 1. Jibson et al., (2000) found that disrupted soil slides typically extended to depths of 1 to $2 \mathrm{~m}$ and Sitar and Clough (1983) similarly observed that such failures rarely exceeded 2 to $3 \mathrm{~m}$ for slopes of $30^{\circ}-60^{\circ}$. Therefore, we assumed a failure plane thickness of $t=2 \mathrm{~m}$ for this work. We also adopted a conservative root cohesion value of $c_{r}=2 \mathrm{kPa}$ based on empirical estimates provided by Terwilliger and Waldron (1991) and Schmidt et al. (2001) for Southern California, where vegetation is similar to that in 
our study area of Lebanon. Static factor-of-safety values were related to expected coseismic displacements using Equations 2 and 3.

\subsubsection{Coherent rotational slides}

To analyze coherent, slump-like, rotational slides in a pixel-based GIS platform we developed a uniform idealized failure surface that combines larger hillslope conditions with individual pixel properties (i.e. $c$ and $\phi$ ). We first determined local hillslope relief $(H)$ via moving window analysis of varying sizes to best capture the scale of the local landscape. We then assumed the radius of a circular failure plane $(R)$ acting through a dry homogeneous hillslope would be one and a half times the local relief $(R=1.5 H$, Fig. 1C). By constraining $\mathrm{R}$ and assuming a circularsegment shaped failure body, we compute the internal angle $\left(\delta=\sin ^{-1} \frac{1}{3 \sin \beta}\right.$, for $\left.\beta>20^{\circ}\right)$ and failure plane length $(L=2 \delta R[\mathrm{~m}])$. Adopting the solution for yield acceleration developed by Kim and Sitar (2004) for an ordinary method of slices analysis, and projecting our 2D circular failure across each pixel as a cylindrical surface of width $y$, yield accelerations were computed on a per-pixel basis for dry slopes using a single slice calculation as:

$k_{y}=\frac{c L y+W(\cos \beta \tan \phi-\sin \beta)}{W\left(\frac{a}{R}+\sin \beta \tan \phi\right)}$ Equation 5 Here, $a$ is the vertical distance between the center of the slip circle and the landslide body's centroid $\left(a=\left(\frac{4 R \sin ^{3} \delta}{3(2 \delta-\sin 2 \delta)}-R\right) \cos \delta[\mathrm{m}]\right), W$ is the weight of the sliding mass $(W=$ $\left.\frac{1}{2} \gamma y R^{2}(2 \delta-\sin 2 \delta)[\mathrm{kN}]\right)$, and $y$ is the cell size of the assessed pixel. Other terms $\beta, c$, and $\phi$ are as defined in Equations 1 and 4. Coseismic displacements were then estimated using Equation 3, with a 50\% reduction factor applied to the PGA to account for the compliant (i.e., non-rigid) nature of large coherent failure masses. In compliant materials, ground motion 
incoherence serves to reduce the destabilizing inertial forces within the soil failure mass (e.g. Kramer and Smith, 1997; Wartman et al., 2003). The 50\% reduction value was chosen based on a comprehensive series of dynamic response analyses by Cetin et al. (2004).

\subsubsection{Lateral Spreads}

Due to the limited subsurface information typically available for regional scale assessments, we adopted a simplified lateral spread hazard assessment procedure based on liquefaction susceptibility indices and displacement estimation procedures developed for HAZUS (FEMA, 2003). As a soil liquefaction-related phenomenon, lateral spreading fundamentally differs from other coseismic failure modes due to its dependency on pore water pressure generation in soils that are encountered in a narrow range of depositional settings. We assumed that only low-lying soils (elevation $<25 \mathrm{~m}$ ) or deposits found near (within $25 \mathrm{~m}$ ) rivers would be susceptible to lateral spreading. We assigned Youd and Perkins (1978) PGA thresholds for liquefaction triggering to susceptible soil units based on depositional conditions, ages, and sand-clay-gravel contents. These PGA triggering thresholds $\left(T_{P G A}\right)$ ranged from a low of $0.12 \mathrm{~g}$ for highly susceptible soils (e.g. recent sandy alluvium) to $0.26 \mathrm{~g}$ for soils having a lower susceptibility to liquefaction (e.g. Holocene-age cohesionless marine terraces). A magnitude correction factor $\left(K_{\Delta}\right)$ for lateral spread displacements was assumed to be 1.0 (FEMA, 2003) for probabilistic seismic hazard-based calculations based on a modal earthquake of $\sim$ M7.0. For scenario events, $\mathrm{K}_{\Delta}$ was computed as (FEMA, 2003):

$\mathrm{K}_{\Delta}=0.0086 \mathrm{M}^{3}-0.0914 \mathrm{M}^{2}+0.4698 \mathrm{M}-0.9835 \quad$ Equation 6

Where $\mathrm{M}$ is the earthquake moment magnitude for each scenario event. 
For soils undergoing liquefaction, we estimated lateral spread displacements $(D)$ based on relationships developed by FEMA (2003):

$$
\mathrm{D}=\mathrm{K}_{\Delta} \mathrm{a} \quad \text { where: } \begin{array}{ll}
\mathrm{a}=12 \mathrm{r}-12 & \text { for } 1<r<2 \\
\mathrm{a}=70 \mathrm{r}-180 & \text { for } 2<r<3 \quad \text { for } 3<r<4
\end{array} \text { and } \mathrm{r}=\frac{\mathrm{PGA}}{\mathrm{T}_{P G A}} \quad \text { Equation } 7
$$

\subsection{Relating Coseismic Displacements to Relative Landslide Hazard}

We related coseismic displacements to relative landslide hazard levels (Table 2) based primarily on recommendations in the literature, but also from our field observations of the seismic performance of slopes during major earthquakes (e.g. Wartman et al., 2003; Wartman et al., 2005). For brittle, disaggregated materials, such as those susceptible to disrupted soil sliding and rock-slope failure, Jibson and Michael (2009) designated regions with as low as $1 \mathrm{~cm}$ of sliding block displacement as having a moderate likelihood of landslide occurrence. By contrast, the California Geologic Survey (2008) concluded that more ductile materials, such as those found in rotational slides, can undergo significantly more coseismic deformation $(15 \mathrm{~cm})$ before posing a significant hazard to the built environment that we adopt as a threshold between low and moderate rotational slide hazard. For lateral spreading, Youd and Perkins (1987) observed that events with $D<13 \mathrm{~cm}$ were typically associated with little structural damage, while events with $D=13-50 \mathrm{~cm}$ caused moderate to severe damage, and events with $D>75 \mathrm{~cm}$ resulted in major damage. We adopted a threshold of $50 \mathrm{~cm}$ for high lateral spreading hazard as a more conservative measure than the major damage limit of $75 \mathrm{~cm}$.

\section{Application to Lebanon}


We selected the nation of Lebanon as a test location to apply the multimodal coseismic landslide hazard method. Lebanon was principally selected because of its steep topography, history of large (>M6) earthquakes, and rapidly growing population, which together may produce significant coseismic landslide risks. Coseismic landslide inventories were not available for Lebanon, precluding the use of regression-based modeling techniques, as is the case for many parts of the world. After describing application and results of the multimodal modeling, we discuss observations from a field reconnaissance across the region that was subsequently undertaken to assess and test the landslide hazard mapping.

\subsection{Geologic and Tectonic Setting}

Lebanon is a small $\left(10,452 \mathrm{~km}^{2}\right)$, mountainous country located along the eastern Mediterranean (Fig. 4). The landscape rises steeply from a narrow $(5-15 \mathrm{~km})$ shelf along the coast where major cities in Lebanon are found (Beirut, Tripoli, and Tyre) to elevations of 2,500-3,000 $\mathrm{m}$ in the Mount Lebanon Range. Numerous deeply incised east-west trending river valleys divide the western slopes of the Mount Lebanon Range, exposing extensive cliffs of sandstone and limestone. East of the Mount Lebanon Range, the landscape drops steeply over sparsely vegetated slopes to the Yammouneh fault, the major left-lateral restraining bend of the Levant Fault System. From the Levant Fault System, the terrain slopes gently to the Bekaa Valley, a major agricultural region. Continuing east, the relatively barren limestone mountains of the AntiLebanon Range rise to $\sim 2,500$ m over rolling hillslopes that form Lebanon's border with Syria.

Geologic units in Lebanon are principally limestone and sandstone, dating back to the Early Jurassic. Four of these units, Kesrouane Limestone, Sannine Limestone, Chouf Sandstone, and 
the Mdairej Limestone, dominate the landscape. The early Jurassic Kesrouane Limestone was deposited in a shallow sea during a period of tectonic quiescence in the region (Walley, 1988; 1998) and today is a structurally complex and often thick limestone unit that underlies much of the mid-elevation Mount Lebanon region. Uplift of Lebanon in the early Cretaceous allowed for the deposition of the Chouf Sandstone across a then flat, low lying region. The Chouf Sandstone unit, which overlies Jurassic limestone, is widespread and highly fractured. Sea-level rise during the Late Cretaceous led to the further deposition of limestones (Sannine and Mdairej), which were later uplifted to form the modern Mount Lebanon and Anti-Lebanon ranges. This sea-level rise was followed by lateral offset of the Levant Fault System beginning about 10 m.y. ago (Walley, 1988). Today, the Sannine Limestones form the highest slopes of the Mount Lebanon range and are largely structurally intact. The older Mdjairej Limestones form a nearly continuous band of cliffs at mid to high elevations and are a major source of rockfall.

The regional tectonics shaping Lebanon are dominated by three zones of movement. The offshore Mount Lebanon Thrust (MLT) is undergoing compressional displacements of 1.0-2.0 $\mathrm{mm} / \mathrm{y}$ (Elias et al., 2007). The most significant historic earthquake along the Mount Lebanon Thrust was a tsunamigenic $\sim$ M7.2 earthquake in 551C.E. that triggered large landslides in the Hamat area near the coast (Abdallah, 2007). The Yammouneh fault, which bisects the length of Lebanon and bends eastward to compress and uplift the Mount Lebanon Range, is slipping at an estimated rate of $5.1 \pm 1.3 \mathrm{~mm} / \mathrm{y}$ and has been linked to historic $\mathrm{M}>7$ earthquakes (e.g. 1202C.E., Daëron et al., 2004). The coupled Rachaiya-Serghaya fault system, a left-lateral strainpartitioning complex through the Anti-Lebanon Range, shows $1.4 \pm 0.1 \mathrm{~mm} / \mathrm{y}$ of movement (Gomez et al., 2003) and produced estimated M6.7 and M7.2 earthquakes in 1759 that destroyed 
much of the region (Elnashai and El-Khoury, 2004). Overall, the nearly 1000-year historic record of the region reveals a pattern of large earthquakes clustered in time (with decade intervals, most recently in the late 1700s) between longer 200 - 350 year periods of quiescence (Ambraseys and Barzangi, 1989). Huijer (2010) and Huijer el al. (2011) aggregated the three major seismic sources in the region to produce the PGA values used in this work.

\subsection{Landslide Susceptibility Zones}

We studied the coseismic landslide hazard across all of Lebanon. Previous work in Lebanon on landslide susceptibility and detection (e.g. Abdallah, 2010; Abdallah et al., 2007; Khawlie and Hassanain, 1984) has focused on the rugged western slopes of the Mount Lebanon Range, where near-vertical limestone cliffs, long talus slopes, and extensive hillslopes of relatively steep $\left(>20^{\circ}\right)$ terrain cover the landscape. East of Ain Mouaaffaq, near Hammana, Khawlie and Hassanain (1984) identified active and former slope failures involving translational and rotational slides, block failures, toppling, and complex failures, while Abdallah (2010) identified slides and falls of unknown origin across the northwest of Lebanon. Less well studied were the gently sloping Bekaa Valley, the karstic Anti-Lebanon mountains, and the alluvial valleys in the south of Lebanon (Fig. 4). We estimated soil and rock strength parameters (c and $\phi)$ based on available geologic and soil mapping and data presented in published studies (Dubertret, 1945; Geze, 1956; Abdallah, 2007), unpublished engineering consulting reports, and in consultation with geotechnical professionals practicing in the area. Rock and soil parameters used in this work are summarized in Table 3. A DEM was developed at a resolution of $15 \mathrm{~m}$ by digitizing contours from 1:20,000 scale topographic map of the country (DGA, 1963). For rock-slope failures and coherent rotational slides a range of window sizes were tested to best capture 
relevant topographic features for local relief calculations. For both landslide types a window of $75 \mathrm{~m}$ was selected to best represent the scale of hillslopes active in these failure modes. The unit weight of all rock materials was assigned a nominal value of $23 \mathrm{kN} / \mathrm{m}^{3}$, which is typical of the limestone, sandstone, and marl units that occur throughout the region. Soil unit weights were assigned a uniform value of $20 \mathrm{kN} / \mathrm{m}^{3}$ based on typical values for sands and gravels (Lambe and Whitman, 1969). As a first order attempt to incorporate the reinforcing effects of vegetation on a hillslope, relative NDVI values were used to identify regions of vegetation cover across our study region based on Landsat 8 images from May 2014. Given the similarities in climate and vegetation between Lebanon and southern California, we assumed a conservative value of root cohesion of $2 \mathrm{kPa}$, which was applied over the most heavily vegetated portions of our study region (i.e., regions in the top $10 \%$ of relative NDVI for Lebanon).

Figure 5 shows landslide susceptibility modes based on topographic criteria. Steep $\left(>35^{\circ}\right)$, highly susceptible terrain comprise $5 \%$ of the country, while areas assumed to have a low susceptibility coseismic landslide hazard (i.e., slopes from $6^{\circ}$ to $15^{\circ}$ ) is found across $45 \%$ of the country. When lateral spread susceptibility criteria (i.e., age of deposit and setting; Section 2.2.4) are applied, approximately $75 \%$ of the region classifies as having a low susceptibility to coseismic landslides. Of the zones categorized as being susceptible to shallow disrupted slides, about $8 \%$ were assigned root cohesion-enhanced soil strengths based on the NDVI criterion. These vegetation-reinforced slopes are concentrated along the alluvial valleys of western Lebanon. In the rugged Mount Lebanon Range, hillslopes steeper than $35^{\circ}$ slopes extend for many kilometers along the repeating east-west alluvial valleys located below scattered cliff bands. Our field observations of these steep hillslopes in the Mount Lebanon Range revealed 
localized areas of actively eroding rock cliffs above long, steep, and loose talus deposits.

Observations from past seismic events in other regions suggest that these steep slopes would be highly susceptible to rock-slope failure (e.g. Wartman et al. 2013). Further east, below the bare scree slopes of the eastern Mount Lebanon Range slope lies the flat Bekaa Valley, where lateral spreading susceptibility was indicated along the major rivers. The sparsely vegetated, open slopes of the Anti-Lebanon Range (eastern portions of Fig. 5), where gently sloped $\left(<35^{\circ}\right)$ ridges trend from northeast-southwest to east-west, were shown to be susceptible to disrupted and coherent rotational slides. To the south, shallow alluvial valleys meander across gentle $\left(6^{\circ}-35^{\circ}\right)$ slopes, with only the region's major river, the Litani, producing slopes prone to localized rockslope failures or more widely distributed disrupted soil slides.

\subsection{Coseismic Landslide Hazards}

Huijer (2010) and Huijer et al. (2011) conducted probabilistic seismic hazard analyses (PSHA) for Lebanon and developed the $10 \%$ chance of exceedance in 50 years (475-year return period) peak ground acceleration estimate that was adopted for this study (Fig. 6). For 475-year return period PSHA peak ground accelerations, our analysis identified areas having a high disrupted soil slide and rock-slope failure hazard along the steeply incised river valleys of the Mount Lebanon Range (Fig. 6A, near Bcharre) and along the Litani River canyon near Yohmor (Fig. 6B). We did not find densely concentrated high coseismic landslide hazard zones for these disrupted modes of failure in other parts of the country. Isolated cliff bands and talus slopes across the western portion of the country exhibit a low to moderate hazard that is limited to small, localized zones. For 475-year return period ground motion inputs, no significant (low, moderate, or high) hazard was predicted for coherent rotational sliding. Moderate to high lateral 
spreading hazard was shown in recent deposits located along the coast and Litani River of the Bekaa Valley (Fig. 6B near Yohmor). The highest concentration of high lateral spread hazard was identified near Beirut, where anthropogenic fill and alluvial deposits lie close to the MLT fault, which produces high PGA values in this local area.

Strong motion recordings of significant (>M6.0) earthquakes in Lebanon's history do not exist, but the long history of estimated M6.5+ earthquakes in the region motivated an analysis of specific seismic scenarios to further explore potential landslide hazards. We considered several deterministic scenario events that dominate the seismic hazard of the region. Figures 7 and 8 present results for two such PSHA disaggregation-derived scenarios: a M7.2 Mount Lebanon Thrust and M6.6 Rachaiya fault events. For both events, PGA distributions were estimated using the Scenario Shakemap application (Field et al., 2003).

The Mount Lebanon Thrust (MLT) scenario earthquake (Fig. 7) was modeled as occurring on an $80 \mathrm{~km}$ long fault plane that dips $45^{\circ}$ towards the coast. Fault geometry was based on the work of Arango and Lubkowski (2012) and Elias et al. (2007). This event produced shaking intensities and distributions that are probably similar to the 551C.E. M7.2 earthquake on the MLT that destroyed many coastal cities, included Beirut and Tripoli. Widespread moderate and high hazard is predicted for disrupted soil slides and rock-slope failures is indicated in the steep, unvegetated valley walls west of Bcharre (Fig. 7A), where only limited hazard is shown for PSHA shaking (Fig. 6A). Along the coast near Journieh (Fig. 7B), where modeled shaking is locally in excess of $0.5 \mathrm{~g}$, pockets of low - high hazard is indicated for disrupted soil slides and rock-slope failures. A band of low rotational slide hazard is shown just east of Jounieh but not 
along the more inland alluvial valleys susceptible to this mode of failure near Darayia (Fig. 7A) where predicted shaking is $\sim 0.2 \mathrm{~g}$.

The Rachaiya earthquake scenario was modeled as a $55 \mathrm{~km}$ long, left-lateral strike-slip event rupturing vertically from 5 to $10 \mathrm{~km}$ below the ground surface. The location and trace of the fault were selected to approximate the M6.6 earthquake that occurred in October of 1759 along the Rachaiya fault (Nemer et al., 2008). Few high hazard zones for all modes of landslides are found as most hillslopes are more weakly shaken in comparison to the PSHA (Fig. 6). High and moderate levels of hazard are predicted in rock-slope failure and disrupted soil sliding modes along isolated slopes near Yohmore and Ouardiye (Fig. 8A) where predicted shaking ranges from $0.2-0.4 \mathrm{~g}$. Low hazard predictions were also made in isolated locations for coherent rotational sliding. Results from this scenario suggest that earthquakes within the Anti-Lebanon Range, although large, may not produce the widespread landslide damage that would occur from a coastal or Yammouneh fault earthquake.

\subsection{Field Assessment}

Following the development of multimodal coseismic landslide hazard maps for Lebanon, we undertook a multiday field reconnaissance across the region to qualitatively assess the results. In addition to the broader-scale reconnaissance across the region, we stopped to make comprehensive assessments at 30 specific sites. These assessment sites were selected such that all predicted modes of failure would be observed in the field. Additionally, this allowed us to more closely investigate local areas where our knowledge of the region suggested that landslide hazards may have been over-estimated, or conversely, omitted. During the fieldwork, we 
recorded evidence of past slope instability and assessed landslide susceptibility and likely mode of failure based on our professional experience from past post-earthquake reconnaissance investigations. We then compared our field observations to our multimodal landslide hazard maps.

Overall, we found that locations designated as having a high hazard corresponded closely to the observed landslide-susceptible terrain. For example, active rock sources, such as the Mdairej limestone cliffs across the Mount Lebanon Range, were consistently mapped as moderate to high rock-slope failure hazards. Soils developed from the Chouf Sandstone and steep talus slopes were found in most regions of high disrupted soil slide hazard. Coherent rotational landslides were only observed across limited regions near Bcharre, Darayia (Fig. 7A), and Hamat (Fig. 9A). The large rotational landslides observed near Hamat have been linked to the 551C.E. MLT M7.2 earthquake (Abdallah, 2007), although no clear triggering mechanism is associated with other observed slides. We found no surficial evidence of lateral spreading or liquefaction, as these subtle morphological features are unlikely to survive after the last major earthquake in Lebanon (1759). Nonetheless, the locations exhibiting a lateral spread hazard corresponded closely to the types of settings where this phenomenon has been routinely observed in past earthquakes.

Our detailed site evaluations were conducted at 30 individual sites; however, for brevity we will limit our discussion to two locations that provide site-specific scale examples of how the terrain classified within our multimodal landslide hazard method. 
Hamat: Near Hamat (Fig. 9A-B) we observed hillslopes susceptible to all considered landslide modes. Hillslopes near Hamat were observed to have short, near vertical, cliffs above alternating zones of planar talus and heavily tree-covered material at angles of $\sim 30^{\circ}$ in slope. Hillslopes in this location are $\sim 150 \mathrm{~m}$ tall and are composed of the weak Cretaceous Chekka Formation (off white unit exposed as a cliff in Fig. 9B) capped by a thin gray Miocene age limestone (top-left of Fig. 9B.) Abdallah (2007) linked large coherent landslides near Hamat with large MLT earthquakes. In our MLT scenario output, we predict low levels of hazard for coherent rotational slides similar to large rotational movements observed in Hamat, as well as low to high levels of rock-slope failure and disrupted soil slide hazard in the headscarp-cliff and talus portions of the slopes.

Ain Mouaaffaq: At this site we observed complex soil failures in residual soils of the Cretaceous Chouf Sandstone below a major roadway (Fig. 9C-D). Landslide movement was observed to be primarily translational over the entire slope, developing locally over-steepened soil and weathered rock-slopes. Susceptibility mapping identified the potential for disrupted soil sliding, without applying root cohesion, and rock-slope failures. PSHA-based hazard analysis predicted low to high disrupted soil landslide hazard increasing with local slope, but no rock-slope failure hazard in the over-steepened soil-rock cliffs observed in the slide.

\subsection{Discussion}

Across Lebanon, our coseismic landslide hazard assessment matched both the anticipated mode of failure based on our field reconnaissance and the expected location of potential instability. We found that the mapping was able to resolve many small (single $15 \mathrm{~m}$ pixel), localized outcrops 
(often with recent or incipient landslides) and to correctly identify these as hazards. Similarly, larger kilometer-long stretches of highly localized slope hazard were found to properly corresponded to extensive stretches of potentially unstable cliffs. Distinctive landforms, from limestone cliffs and talus to soil-mantled alluvial valleys, were consistently matched to predicted or observed modes of failure following the multimodal procedure. Overall, the field observations suggest that the multimodal assessment method is capable of identifying the location, expected mode, and coseismic landslide hazard level.

In addition to utilizing geotechnical models tailored to a specific mode of failure, the multimodal method allows explicit consideration of the possible consequences of failure and thus could be used to support regional-scale coseismic landslide risk assessment. For example, widespread lateral spread potential along the Hamat coast (Fig. 10A) may be expected to cause structural damage to structures and infrastructure without posing any significant human fatality risk. In contrast, the combination of the high rock-slope failure hazard and steep underlying slopes near the village of Kfour El Aarbi (Fig. 10B) may produce numerous rockfalls capable of impacting homes in the village, thus posing a risk to life. Coherent rotational landslide hazards near Hamat (Fig. 9B) could damage a small coastal road, but likely pose a lesser risk to life and private property.

The PSHA and deterministic earthquake events each produce different landslide hazard patterns and highlight insights provided by considering a range of seismic scenarios. As an aggregate of multiple potential earthquakes across a large region, the PSHA-derived ground shaking intensities provided an understanding of the long-term, collective hazard across Lebanon. In 
contrast, single scenarios such as the potential Rachaiya and MLT events produce tightly constrained regions of mapped landslide hazard and delineate sub-areas where specific types of landslides are likely to occur for a given event. Scenario earthquakes also allow for the distributions of lateral spreading susceptibility to be investigated since PSHA-derived PGA values produce geospatial patterns of lateral spreading potential that appear to under-predict the hazard when compared to scenario events. It should be recognized that the probabilistic and deterministic assessments are associated with events having different seismic hazard levels (i.e., return periods), and therefore a direct comparison of results is not possible.

Traditionally, regional-scale coseismic hazards assessments have assumed all landslides fail as shallow infinite slopes. This assumption oversimplifies the landslide hazard and fails to consider other common modes of failure and their respective characteristics and consequences. Therefore, worth comparing the results of the multimodal hazard assessment with that of a traditional infinite slope based model. Figure 11 presents the infinite slope hazard predictions with results of the multimodal analysis near Hamat. Adopting our disrupted soil slide displacements for hazard predictions of infinite slope analysis, the overall patterns of hazard prediction are similar for the two approaches, but the multimodal analysis provides a richer and more descriptive mapping of landslide hazards along the valley. The multimodal method indicates coherent rotational landslide hazards throughout the hillslopes near Hamat, while the corresponding infinite-slope based approach shows no landslide hazard at this location. Both the multimodal and traditional infinite slope methods indicate a shallow soil sliding hazard throughout the hillslope, but this zone is significantly more localized and narrow for the multimodal assessment as a result of the slope thresholds adopted in this work. In the northern and southern portions of the hillslope, 
isolated cliffs develop rock-slope failure hazard in the multimodal method that is captured, but not differentiated, by the infinite slope analysis. Finally, in the northern portion of Fig. 11, sandy beach deposits are shown as a potential lateral spread hazard while the infinite slope analysis indicates no hazard at this location. Discrepancies between the multimodal and traditional infinite slope methods are principally due to the use of mode-specific geotechnical models (versus solely infinite slope formulations) across the region.

Given the relative lack of data traditionally used to assess liquefaction (e.g. geotechnical test borings), several simplifying and conservative assumptions were adopted to evaluate lateral spread potential at a regional scale. Among these were that low-lying elevations along the Mediterranean Sea and locations along rivers were assumed to be uniformly saturated. Clearly, groundwater conditions at these sites are more complex and likely to fluctuate in time. In the event of an earthquake it is expected that some fraction of areas mapped as lateral spread hazards will fully liquefy and subsequently spread. Thus, the spatial accuracy of the lateral spread hazard mapping will likely be less than that of other modes of coseismic landslides.

We utilized a 15 m resolution DEM for our work, which was able to capture a range of terrain features across Lebanon, including steep river channels in the north, long cliff bands through the central region, and rolling valleys to the south. Although Lebanon served as a test location for this research, we believe the multimodal procedure can also be used in other places where DEM data and information on geologic properties are available. For areas where only coarser resolution DEMs (>15 m) are available, we expect that the slope thresholds may need to be decreased (or increased for higher resolution data) to reflect the resolution with which the DEM 
cam represent the true morphology of the land surface (Zhang et al., 1999) and zones susceptible to landslides. It should also be recognized that the window dimension used to determine slope heights for rock-slope failures and coherent rotational slides $(75 \mathrm{~m})$ reflects the general scale of terrain features in Lebanon. This dimension may require modification for use in locations having significantly different landforms.

\section{Conclusions}

Landslides are a significant and widely distributed secondary seismic hazard during earthquakes. Landslide reconnaissance following past earthquakes has revealed a range of coseismic failure modes. In this paper, we presented a new multimodal landslide hazard assessment methodology that considers four common modes of coseismic failure: rock-slope failures, disrupted soil slides, coherent rotational slides, and lateral spreads. Susceptibility to a specific landslide mode is determined by topographic slope, which is shown to correspond closely with observed landslide activity across Lebanon. Geotechnical models specific to each mode of failure are then used to assess stability and estimate coseismic displacements based on probabilistic or deterministic seismic scenarios. Across Lebanon, field verification of $\sim 30$ sites showed close agreement between the landslide susceptible terrain and hazard mapping, and the expected seismic performance of slopes. The multimodal method thus provides an inexpensive, rapid, automated procedure for assessing coseismic landslide hazards over a regional scale.

\section{Acknowledgments}

Financial support for this research was provided by the U. S. National Science Foundation under Grant Nos. 0936602 and 1548552 and the U. S. Agency for International Development (USAID) 
under PEER grant 1-163. The opinions, findings, and recommendations expressed in this article are those of the authors and do not necessarily reflect the views of these agencies. The thoughtful comments provided by anonymous reviewers improved this paper. 


\section{References}

Abdallah C (2007) Application of remote sensing and geographic information systems in the study of ground movements in Lebanon. Dissertation, University Pierre et Marie Curie-Paris VI

Abdallah C (2010) Spatial distribution of block falls using volumetric GIS-decision-tree models. International Journal of Applied Earth Observation and Geoinformation, 12(5), 393-403

Abdallah C, Chorowicz J, Boukheir R, Dhont D (2007) Comparative use of processed satellite images in remote sensing of mass movements: Lebanon as a case study. International Journal of Remote Sensing, 28(19), 4409-4427

Allstadt K, Vidale JE, Frankel AD (2013) A scenario study of seismically induced landsliding in Seattle using broadband synthetic seismograms. Bulletin of the Seismological Society of America. 103(6): 2971

Ambraseys NN, Barazangi, M. (1989) The 1759 earthquake in the Bekaa Valley: implications for earthquake hazard assessment in the Eastern Mediterranean region. Journal of Geophysical Research: Solid Earth (1978-2012), 94(B4), 4007-4013

Arango, M. C., Lubkowski, Z. A. (2012) Seismic Hazard Assessment and Design Requirements for Beirut, Lebanon. In 15th World Conference in Earthquake Engineering. 
Bartlett SF, Youd TL (1995) Empirical prediction of liquefaction-induced lateral spread. Journal of Geotechnical Engineering, 121(4), 316-329

Bommer JJ, Rodríguez CE (2002) Earthquake-induced landslides in Central America. Engineering Geology, 63(3), 189-220

California Geological Survey (2004) Recommended criteria for delineating seismic hazard zones in California: California Geological Survey Special Publication, 118 (12 pp.)

California Geological Survey (2008) Guidelines for Evaluation and Mitigating Seismic Hazards in California: California Geological Survey Special Publication, 117A (98pp.)

Cetin KO, Seed RB, Der Kiureghian A, Tokimatsu K, Harder Jr LF, Kayen RE, Moss RE (2004) Standard penetration test-based probabilistic and deterministic assessment of seismic soil liquefaction potential. Journal of Geotechnical and Geoenvironmental Engineering, 130(12), $1314-1340$

Corominas J, Van Westen C, Frattini P, et al., (2014) Recommendations for the quantitative analysis of landslide risk. Bulletin of engineering geology and the environment, 73(2), 209-263

Cubrinovski M, Taylor M, Robinson K, et al. (2014) Key factors in the liquefaction-induced damage to buildings and infrastructure in Christchurch: Preliminary findings. Auckland, New 
Zealand: 2014 New Zealand Society for Earthquake Engineering Conference (NZSEE), 21-23 Mar 2014. 9pp.

Daëron M, Benedetti L, Tapponnier P, Sursock A, Finkel RC (2004) Constraints on the post $\sim 25$ ka slip rate of the Yammoûneh fault (Lebanon) using in situ cosmogenic 36Cl dating of offset limestone-clast fans. Earth and Planetary Science Letters, 227(1), 105-119

Dai FC, Xu C, Yao X, Xu L, Tu XB, Gong QM (2011) Spatial distribution of landslides triggered by the 2008 Ms 8.0 Wenchuan earthquake, China. Journal of Asian Earth Sciences, 40(4), $883-895$

de Magistris FS, Lanzano G, Forte G, Fabbrocino G (2013) A database for PGA threshold in liquefaction occurrence. Soil Dynamics and Earthquake Engineering, 54, 17-19

DGA, Direction of geographic affairs (1963) Topographic maps at a scale 1:20,000. Republic of Lebanon

Dreyfus D, Rathje EM, Jibson RW (2013) The influence of different simplified sliding-block models and input parameters on regional predictions of seismic landslides triggered by the Northridge earthquake. Engineering Geology, 163, 41-54 
Dubertret L (1945) Cartes géologiques à l'échelle de 1/50 000 (Hamidieh, Halba, Batroun, Tripoli, Sir El Dannieh, Jbail, Qartaba, Baalbeck, Beirut, Zahle, Rayak, Saida, Jezzine, Rachaya). République Libanaise, Ministère des Travaux publics, Beyrouth, Liban.

Duncan JM, Wright SG, Brandon TL (2014) Soil strength and slope stability. John Wiley \& Sons, Hoboken

Elias A, Tapponnier P, Singh SC, et al. (2007) Active thrusting offshore Mount Lebanon: Source of the tsunamigenic AD 551 Beirut-Tripoli earthquake. Geology, 35(8), 755-758

Elnashai A, El-Khoury R (2004) Earthquake hazard in Lebanon. Imperial College Press, London

Field EH, Jordan TH, Cornell CA (2003) OpenSHA: A Developing Community-Modeling Evnironment for Seismic Hazard Analysis, Seismological Research Letters, 74, no. 4, p. $406-419$

Federal Emergency Management Agency (2003) Multi-Hazard Loss Estimation Methodology. Earthquake Model, HAZUS® MH Technical Manual, National Institute of Building Sciences and Federal Emergency Management Agency, Washington, DC, 690

Godt JW, Sener B, Verdin K, Wald D, Earle P, Harp E, Jibson R. (2008) Rapid assessment of earthquake-induced landsliding. In Proceedings of the First World Landslide Forum, United Nations University, Tokyo 2008 Nov (Vol. 4, pp. 3166-1) 
Gomez F, Meghraoui M, Darkal AN, et al., (2003) Holocene faulting and earthquake recurrence along the Serghaya branch of the Dead Sea Fault system in Syria and Lebanon. Geophysical Journal International, 153(3), 658-674

Harp EL, Jibson RW (1996) Landslides triggered by the 1994 Northridge, California, earthquake. Bulletin of the Seismological Society of America, 86(1B), S319-S332

Huijer CE (2010) Implications of the recent mapping of the offshore thrust fault system on the seismic hazard of Lebanon. Dissertation, American University of Beirut

Huijer C, Harajli M, Sadek S (2011) Upgrading the seismic hazard of Lebanon in light of the recent discovery of the offshore thrust fault system. Lebanese Science Journal, 12(2), 67

Jibson RW (2007) Regression models for estimating coseismic landslide displacement. Engineering Geology, 91(2), 209-218

Jibson RW, Harp EL, Michael JA (2000) A method for producing digital probabilistic seismic landslide hazard maps. Engineering Geology 58, 271-289

Jibson RW, Michael JA (2009) Maps showing seismic landslide hazards in Anchorage, Alaska: U.S. Geological Survey Scientific Investigations Map 3077, scale 1:25,000, 11-p. pamphlet 
Keefer DK (1984) Landslides caused by earthquakes. Geological Society of America Bulletin $95,406-421$

Keefer DK (1999) Earthquake-induced landslides and their effects on alluvial fans. Journal of Sedimentary Research, 69(1)

Keefer DK (2000) Statistical analysis of an earthquake-induced landslide distribution—the 1989 Loma Prieta, California event. Engineering geology, 58(3), 231-249

Keefer DK (2002) Investigating landslides caused by earthquakes-a historical review. Surveys in geophysics, 23(6), 473-510

Keefer DK, (2013) Landslides generated by earthquakes: immediate and long-term effects. In: Shroder, J. (Editor in Chief), Owen LA (Ed.), Treatise on Geomorphology. Academic Press, San Diego, CA, vol. 5, Tectonic Geomorphology, pp. 250-266

Khazai B, Sitar N (2000) Assessment of seismic slope stability using GIS modeling. Geographic Information Sciences, 6(2), 121-128

Khazai B, Sitar N (2004) Evaluation of factors controlling earthquake-induced landslides caused by Chi-Chi earthquake and comparison with the Northridge and Loma Prieta events. Engineering geology, 71(1), 79-95 
Khawlie MR, Hassanain HI (1984) Failure phenomena and environmental control of the relatively unstable Hammana area, Lebanon. Engineering geology, 20(3), 253-264

Kim J, Sitar N (2004) Direct estimation of yield acceleration in slope stability analyses. Journal of geotechnical and geoenvironmental engineering,130(1), 111-115

Kramer SL (1996) Geotechnical Earthquake Engineering, Prentice Hall, Upper Saddle River, NJ

Kramer SL, and Smith MW (1997) Modified Newmark model for seismic displacements of compliant slopes.' J. Geotech. Geoenviron. Eng., 123 (7), 635 - 644

Lambe TW, Whitman RV (1969) Soil Mechanics. John Wiley \& Sons, New York

Lee CT (2013) Re-evaluation of Factors Controlling Landslides Triggered by the 1999 Chi- Chi Earthquake. In: Ugai, K., Yagi, H., Wakai, A. (eds.) Earthquake-Induced Landslides, Springer Berlin Heidelberg, 213-224.

Lee CT, Huang CC, Lee JF, Pan KL, Lin ML, Dong JJ (2008) Statistical approach to earthquake-induced landslide susceptibility Engineering Geology 100 (1), 43-58

Massey CI, McSaveney MJ, Yetton MD, Heron D, Lukovic B, Bruce ZRV (2012) Canterbury Earthquakes 2010/11 Port Hills Slope Stability: Pilot study for assessing life- safety risk from cliff collapse, GNS Science Consultancy Report 2012/57 
Massey CI, McSaveney MJ, Taig T, et al. (2014) Determining rockfall risk in Christchurch using rockfalls triggered by the 2010-2011 Canterbury earthquake sequence. Earthquake Spectra, $30(1), 155-181$

Meunier P, Hovius N, Haines AJ (2007) Regional patterns of earthquake-triggered landslides and their relation to ground motion. Geophysical Research Letters, 34(20)

Meunier P, Hovius N, Haines JA (2008) Topographic site effects and the location of earthquake induced landslides. Earth and Planetary Science Letters, 275(3), 221-232

Nemer T, Gomez F, Al Haddad S, Tabet C (2008) Coseismic growth of sedimentary basins along the Yammouneh strike-slip fault (Lebanon). Geophysical Journal International, 175(3), 10231039

Newmark N, 1965. Effects of earthquakes on dams and embankments. Geotechnique 15, 139_160

Rodriguez CE, Bommer JJ, Chandler RJ (1999) Earthquake-induced landslides: 1980-1997. Soil Dynamics and Earthquake Engineering, 18(5), 325-346

Saygili G, Rathje EM (2008) Empirical predictive models for earthquake-induced sliding displacements of slopes. Journal of Geotechnical and Geoenvironmental Engineering. 134(6), $790-803$ 
Schmidt KM, Roering JJ, Stock JD, Dietrich WE, Montgomery DR, Schaub T (2001) The variability of root cohesion as an influence on shallow landslide susceptibility in the Oregon Coast Range. Canadian Geotechnical Journal, 38(5), 995-1024

Sitar N, Clough GW (1983) Seismic response of steep slopes in cemented soils. Journal of Geotechnical Engineering, 109(2), 210-227

Sitar N, Khazai, B, (2001) Characteristics of Seismically Induced Landslides in Recent Earthquakes, Invited Keynote Paper, Proc. Int. Conf. on Landslides: Causes, Impacts and Countermeasures, M. Kuhne et al., editors, Verlag Gluckauf GmbH, Essen, 227-237

Terwilliger VJ, Waldron LJ (1991) Effects of root reinforcement on soil-slip patterns in the Transverse Ranges of southern California. Geological Society of America Bulletin, 103(6), 775785

Toppe R, (1987) Terrain models-A tool for natural hazard mapping. Avalanche formation, movement and effects, IAHS Publ, 162, 629-638

Walley CD (1988) A braided strike-slip model for the northern continuation of the Dead Sea Fault and its implications for Levantine tectonics. Tectonophysics, 145(1), 63-72 
Walley CD (1998) Some outstanding issues in the geology of Lebanon and their importance in the tectonic evolution of the Levantine region. Tectonophysics, 298(1), 37-62

Wartman J, Rodriguez-Marek A, Repetto P, Keefer DK (2003) Ground Failure. Southern Peru Earthquake of June 21, 2001 Reconnaissance Report, Earthquake Spectra, Vol. 19(A), No. 1, pp. 35-56

Wartman J, Rodriguez-Marek A, Macari EJ, et al. (2005) Geotechnical Aspects of the January 2003 Tecomán, Mexico, Earthquake. Earthquake Spectra, Vol. 21, No. 2, pp. 493-538

Wartman J, Dunham L, Tiwari B, Pradel D (2013) Landslides in eastern Honshu induced by the 2011 Tohoku earthquake. Bulletin of the Seismological Society of America, 103(2B), 1503-1521

Wieczorek GF, Wilson RC, Harp EL (1985) Map showing slope stability during earthquakes in San Mateo Count, California. U.S. Geological Survey Miscellaneous Investigations Map I-1257e, scale $1: 62,500$

Youd TL, Perkins DM (1978) Mapping liquefaction-induced ground failure potential. Journal of the Geotechnical Engineering Division, 104(4), 433-446

Youd TL, Perkins DM (1987) Mapping of liquefaction severity index. Journal of Geotechnical Engineering, 113(11), 1374-1392. 
Zhang X, Drake NA, Wainwright J, Mulligan M (1999) Comparison of slope estimates from low resolution DEMs: Scaling issues and a fractal method for their solution. Earth Surface Processes and Landforms. Aug 1;24(9):763-79. 


\begin{tabular}{|c|c|c|c|}
\hline $\begin{array}{l}\text { Landslide } \\
\text { Category }\end{array}$ & $\begin{array}{l}\text { Modeled } \\
\text { Geometry }\end{array}$ & $\begin{array}{l}\text { Slope } \\
\text { Range }\end{array}$ & Characteristics \\
\hline $\begin{array}{l}\text { Rock-Slope } \\
\text { Failures }\end{array}$ & Wedge & $35^{\circ}-90^{\circ}$ & $\begin{array}{l}\text { Movement by free fall, sliding, and/or rolling. } \\
\text { Run-out often long, tens of meters to } \mathrm{km} \text {. }\end{array}$ \\
\hline $\begin{array}{l}\text { Disrupted Soil } \\
\text { Slides }\end{array}$ & Infinite Slope & $15^{\circ}-50^{\circ}$ & $\begin{array}{l}\text { Movement by sliding. Displacements of } \\
\text { meters to a hundred meters common. }\end{array}$ \\
\hline $\begin{array}{l}\text { Coherent } \\
\text { Rotational } \\
\text { Slides }\end{array}$ & $\begin{array}{l}\text { Circular- } \\
\text { Rotational }\end{array}$ & $20^{\circ}-35^{\circ}$ & $\begin{array}{l}\text { Movement by slumping or rotational sliding } \\
\text { of a coherent mass. Displacement often small } \\
(<2 \mathrm{~m}) \text {, but large displacements have been } \\
\text { reported in many instances }\end{array}$ \\
\hline Lateral Spreads & $\begin{array}{l}\text { Empirically } \\
\text { Developed }\end{array}$ & $0^{\circ}-6^{\circ}$ & $\begin{array}{l}\text { Movement by the translational movement of a } \\
\text { semi-liquid mass. Displacements typically } \\
\text { small }(<2 \mathrm{~m}) \text {, but may be large in the case of } \\
\text { flow failures }\end{array}$ \\
\hline
\end{tabular}

Table 1. Summary of modes of failure considered in this study. Modified from Wartman et al., (2013). 


\begin{tabular}{|c|c|c|c|c|}
\hline & Low Hazard & Moderate Hazard & High Hazard & Primary Reference \\
\hline Rock-Slope Failures & $1-5 \mathrm{~cm}$ & $5-15 \mathrm{~cm}$ & $>15 \mathrm{~cm}$ & $\begin{array}{l}\text { Jibson and Michael } \\
\text { (2009) }\end{array}$ \\
\hline Disrupted Soil Slides & $1-5 \mathrm{~cm}$ & $5-15 \mathrm{~cm}$ & $>15 \mathrm{~cm}$ & $\begin{array}{l}\text { Jibson and Michael } \\
\text { (2009) }\end{array}$ \\
\hline $\begin{array}{l}\text { Coherent Rotational } \\
\text { Slides }\end{array}$ & $5-15 \mathrm{~cm}$ & $15 \mathrm{~cm}-1 \mathrm{~m}$ & $>1 \mathrm{~m}$ & CGS (2008) \\
\hline Lateral Spreads & $0-15 \mathrm{~cm}$ & $15-50 \mathrm{~cm}$ & $>50 \mathrm{~cm}$ & $\begin{array}{l}\text { Youd and Perkins } \\
\text { (1987) }\end{array}$ \\
\hline
\end{tabular}

Table 2. Hazard levels assigned to coseismic displacements for each mode of landsliding 


\begin{tabular}{|c|c|c|c|c|c|c|}
\hline \multirow[t]{2}{*}{ Age } & \multirow[t]{2}{*}{$\begin{array}{l}\text { Formation or } \\
\text { Description }\end{array}$} & \multirow[t]{2}{*}{$\begin{array}{c}\text { Mapped Geologic } \\
\text { Units }\end{array}$} & \multicolumn{2}{|c|}{$\begin{array}{c}\text { Rock-Slope Failures } \\
\text { Coherent Rotational Slumps }\end{array}$} & \multicolumn{2}{|c|}{ Disrupted Soil Slides } \\
\hline & & & Cohesion (kPa) & Phi (deg) & Cohesion (kPa) & Phi (deg) \\
\hline \multirow{13}{*}{ 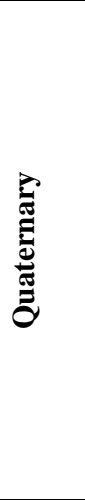 } & \multirow{12}{*}{$\begin{array}{c}\text { Quaternary } \\
\text { Heterogeneous } \\
\text { Deposits }\end{array}$} & qd, qm & 20 & 20 & 20 & 20 \\
\hline & & ql, qs, qta,qaoi & 20 & 30 & 20 & 30 \\
\hline & & $\mathrm{q}, \mathrm{qcg}, \mathrm{ql1}$ & 20 & 25 & 20 & 25 \\
\hline & & qar & 20 & 18 & 20 & 18 \\
\hline & & $\mathrm{a}, \mathrm{ad}$ & 15 & 33 & 15 & 33 \\
\hline & & Alluvium & 15 & 33 & 15 & 33 \\
\hline & & Gravel Slopes & 15 & 33 & 15 & 33 \\
\hline & & Alluvial Fans & 15 & 33 & 15 & 33 \\
\hline & & Silt and Mud & 15 & 33 & 15 & 33 \\
\hline & & Rocky & 25 & 33 & 25 & 33 \\
\hline & & Fill & 15 & 33 & 15 & 33 \\
\hline & & Scree & 25 & 33 & 25 & 33 \\
\hline & Quaternary Basalt & $\mathrm{qb}$ & 20 & 20 & 26 & 24 \\
\hline \multirow{9}{*}{ 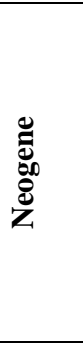 } & \multirow[t]{3}{*}{ Misc. Miocene Units } & $\mathrm{m}$ & 48 & 21 & 32 & 25 \\
\hline & & $\mathrm{m} 2, \mathrm{~m} 2 \mathrm{a}, \mathrm{m} 2 \mathrm{~b}$ & 55 & 25 & 35 & 22 \\
\hline & & $\mathrm{mcg}, \mathrm{ml}, \mathrm{ml} 1$ & 48 & 21 & 14 & 26 \\
\hline & \multirow[t]{2}{*}{ Misc. Pliocene Units } & $\mathrm{p}$ & 57 & 25 & 67 & 22 \\
\hline & & p1 & 62 & 32 & 57 & 26 \\
\hline & \multirow[t]{2}{*}{ Misc. Neogene Units } & $\mathrm{n} 2, \mathrm{n}$ & 58 & 30 & 62 & 25 \\
\hline & & ncg & 62 & 32 & 57 & 26 \\
\hline & \multirow[t]{2}{*}{ Neogene Basalt } & bp,bp1-2,bp3 & 62 & 27 & 27 & 30 \\
\hline & & bn & 52 & 24 & 26 & 24 \\
\hline \multirow{2}{*}{ 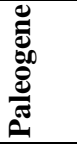 } & \multirow{2}{*}{$\begin{array}{l}\text { Numilitic Eocene } \\
\text { Formation }\end{array}$} & $\mathrm{e} 2, \mathrm{e} 2 \mathrm{a}$ & 42 & 18 & 18 & 21 \\
\hline & & $e 2 b$ & 44 & 20 & 24 & 20 \\
\hline \multirow{8}{*}{ 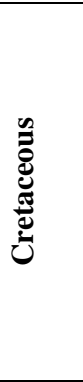 } & Chouf Sandstone & $\mathrm{c} 1, \mathrm{c} 1-2, \mathrm{c} 1-2 \mathrm{a}, \mathrm{c} 2$ & 48 & 21 & 18 & 21 \\
\hline & Abieh Formation & $\mathrm{C} 2 \mathrm{a}$ & 42 & 18 & 47 & 20 \\
\hline & Mdairej Formation & $\mathrm{c} 2 \mathrm{~b}$ & 77 & 34 & 35 & 25 \\
\hline & Hammana Formation & $\mathrm{c} 3, \mathrm{c} 3 \mathrm{~b}, \mathrm{c} 3-4$ & 48 & 21 & 17 & 21 \\
\hline & Sannine Formation & $\mathrm{c} 4, \mathrm{c} 4-5$ & 59 & 24 & 34 & 18 \\
\hline & $\begin{array}{c}\text { Maameltain } \\
\text { Formation } \\
\end{array}$ & $\mathrm{c5}$ & 59 & 24 & 35 & 25 \\
\hline & Chekka Formation & $\mathrm{c} 6$ & 48 & 21 & 18 & 21 \\
\hline & Cretaceous Basalt & $\begin{array}{c}\mathrm{bc}, \mathrm{bc} 1, \mathrm{bc} 2 \mathrm{a}, \mathrm{bc} 2 \mathrm{~b} \\
\mathrm{Bc}\end{array}$ & 56 & 27 & 13 & 24 \\
\hline \multirow{5}{*}{ 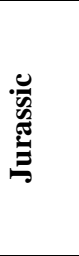 } & Chouane Formation & $\mathrm{j} 1-3, \mathrm{j} 2, \mathrm{j} 3, \mathrm{j}$ & 61 & 26 & 53 & 28 \\
\hline & $\begin{array}{c}\text { Keserouane } \\
\text { Formation }\end{array}$ & $\mathrm{j} 4, \mathrm{j} 6$ & 61 & 26 & 35 & 20 \\
\hline & Bikkfaya Formation & j6a & 84 & 38 & 113 & 34 \\
\hline & Salima Formation & $\mathrm{j} 7$ & 45 & 21 & 35 & 20 \\
\hline & Jurassic Basalt & bj, bj6, bj5 & 52 & 24 & 13 & 24 \\
\hline
\end{tabular}

Table 3. Geologic units and geotechnical properties used in this study. Geologic mapping adopted from Dubertret (1945). 


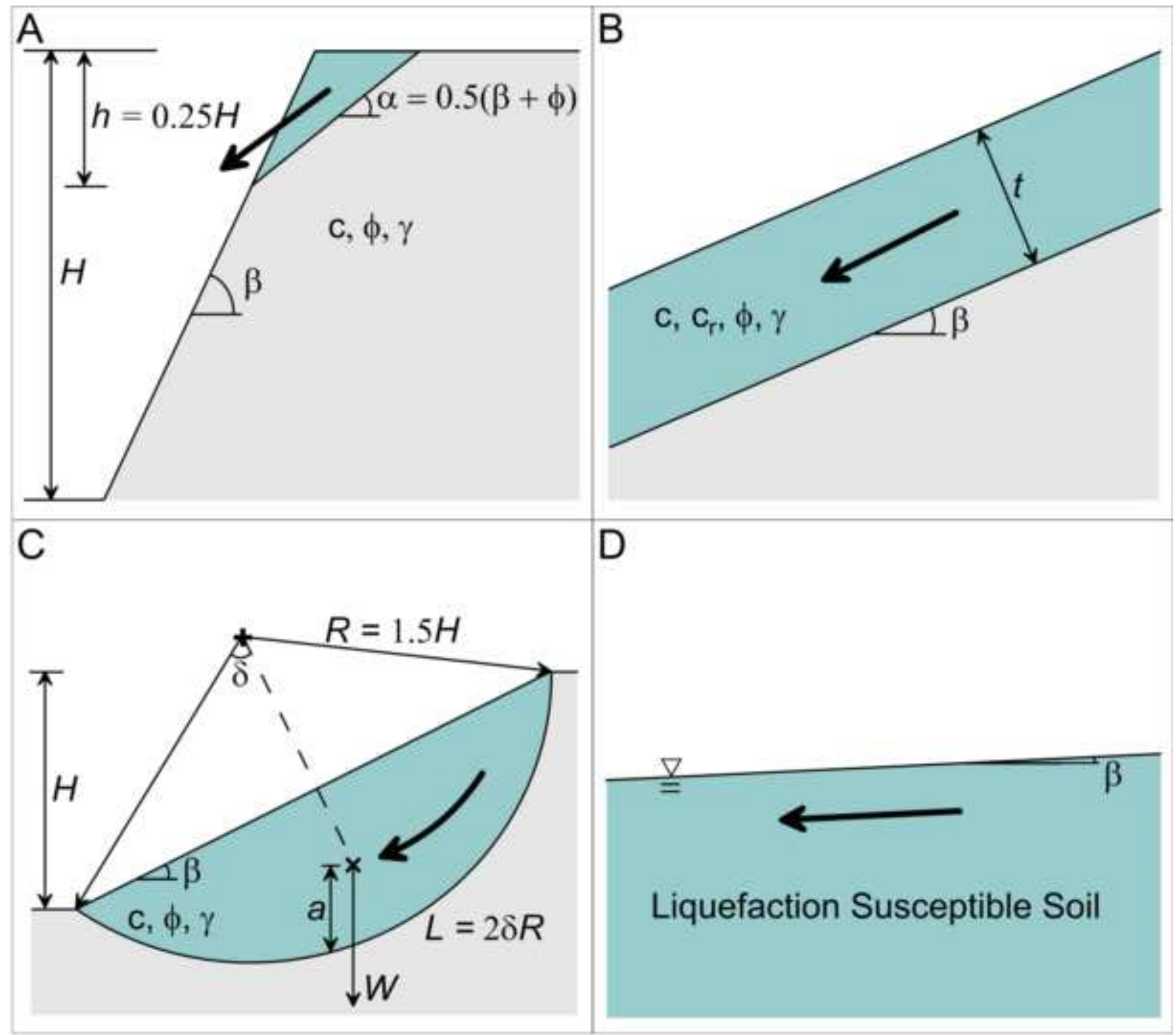




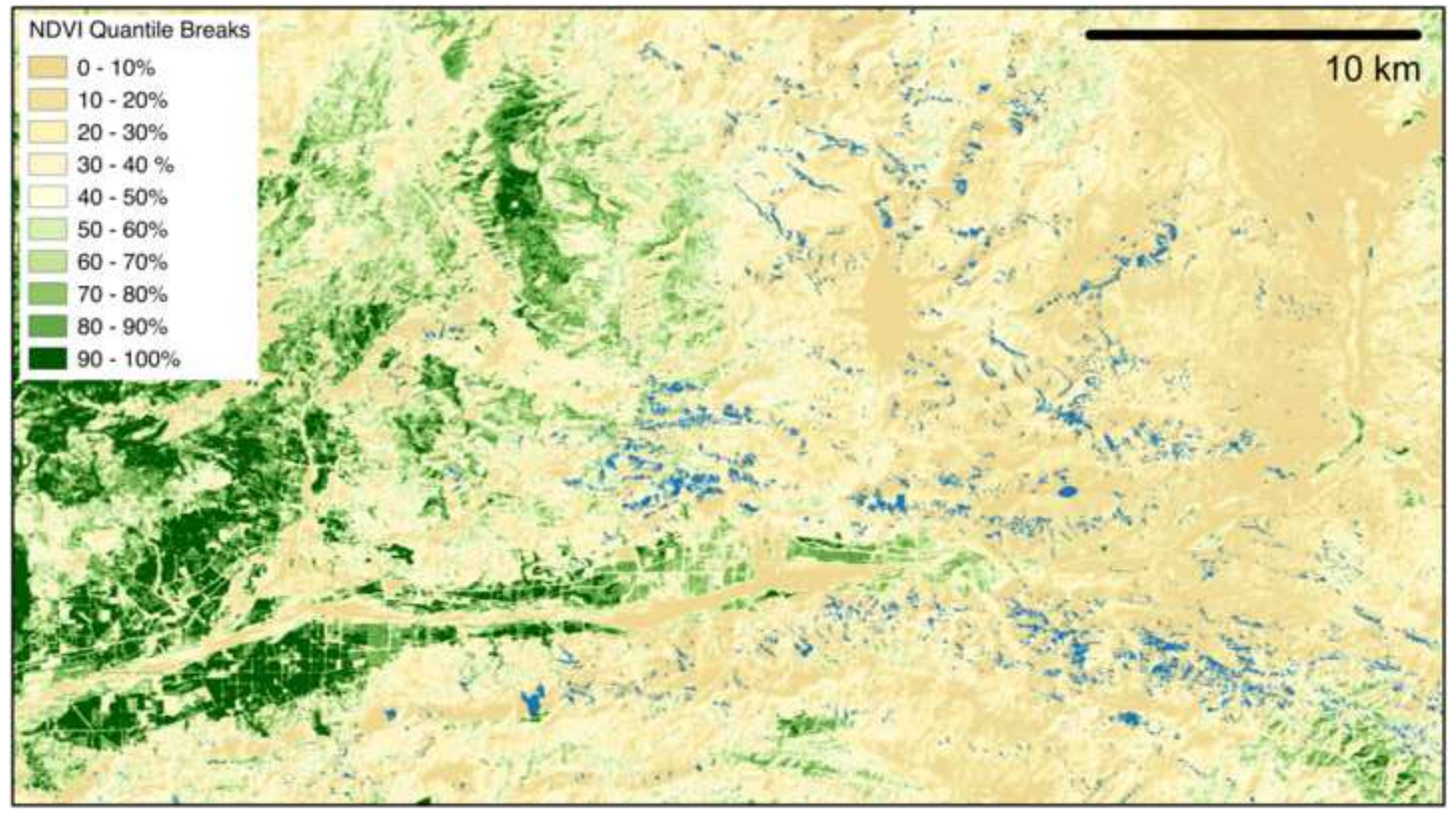




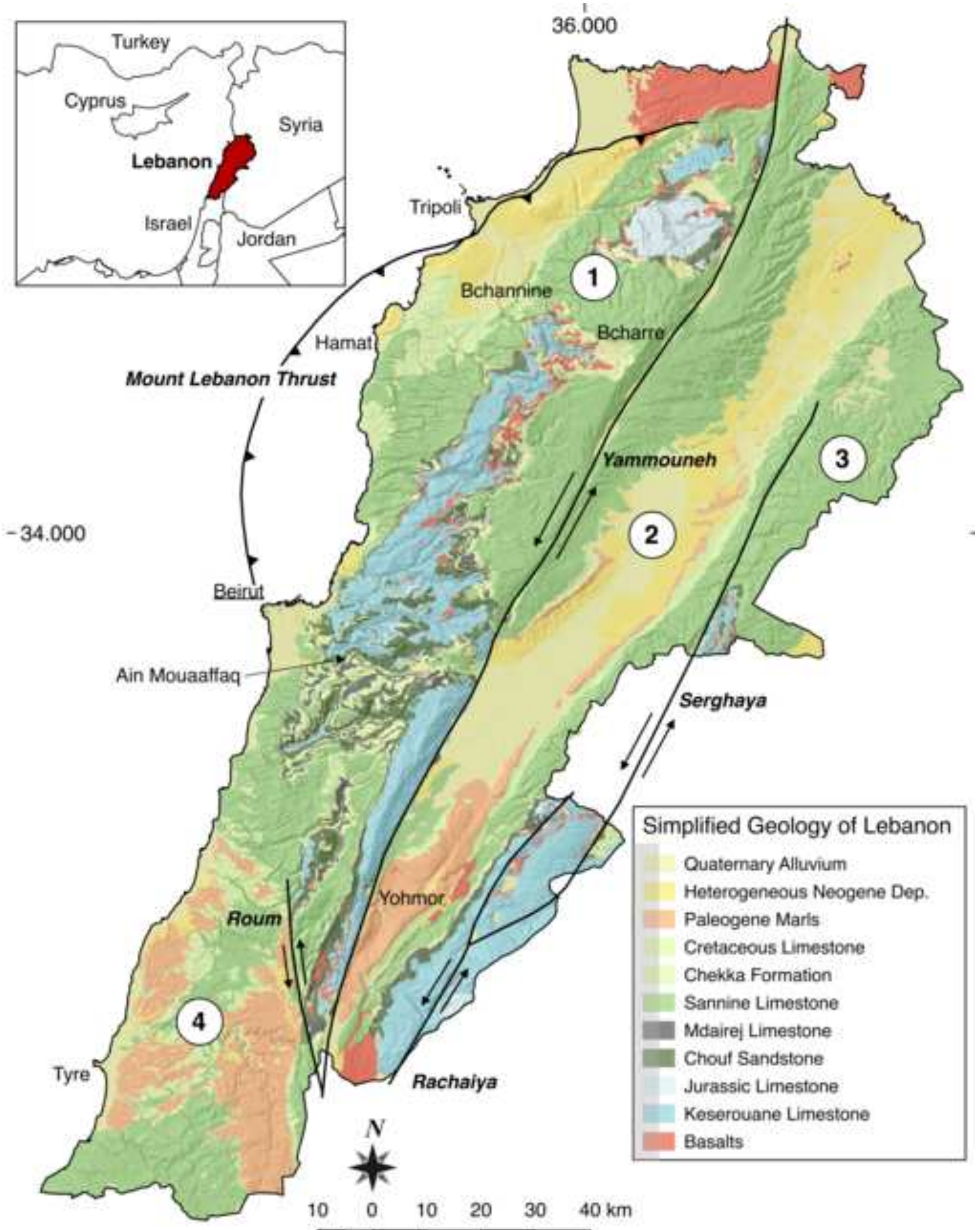

$-33.000$ 


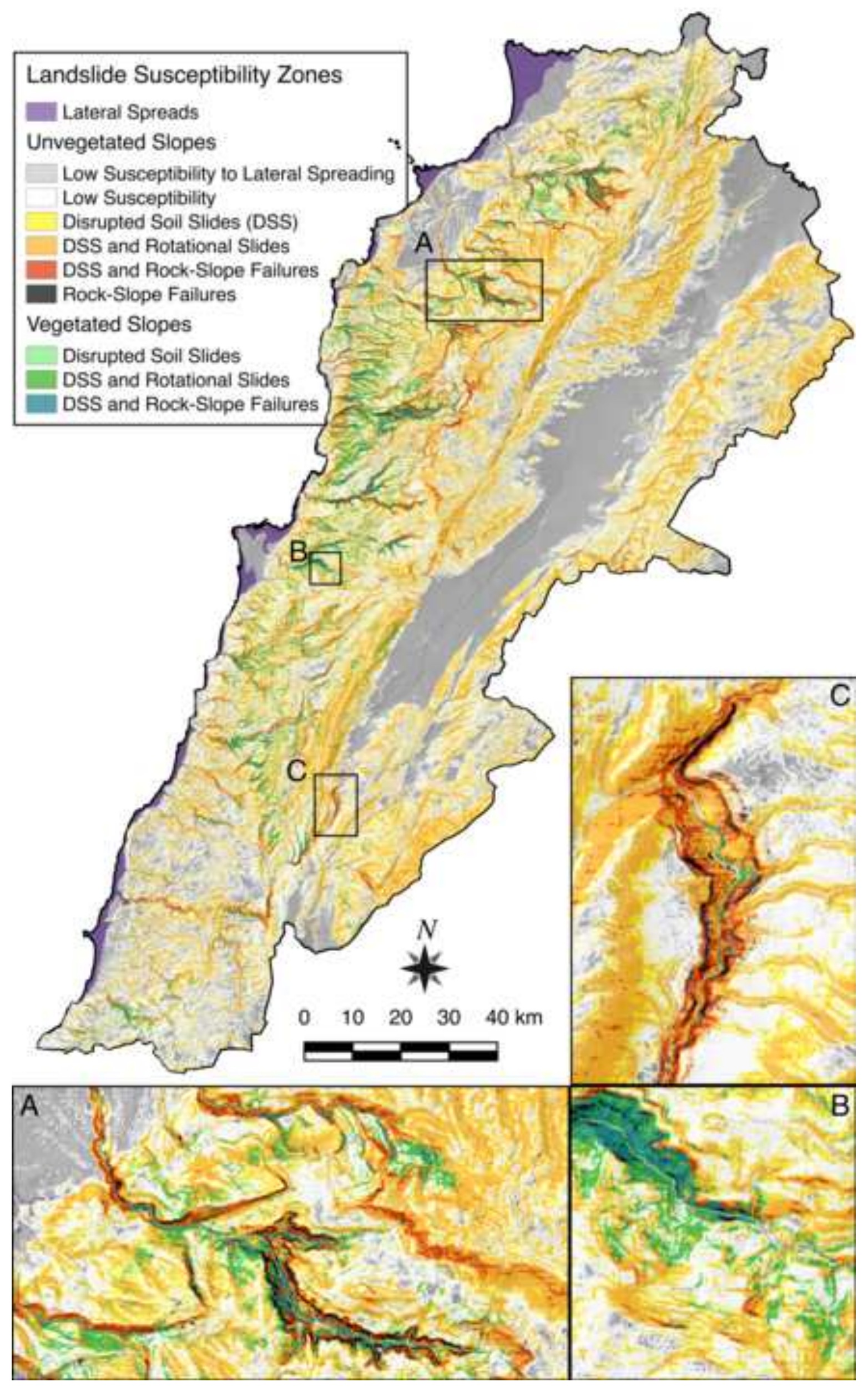

Figure 5

\section{Figure 5}

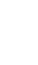

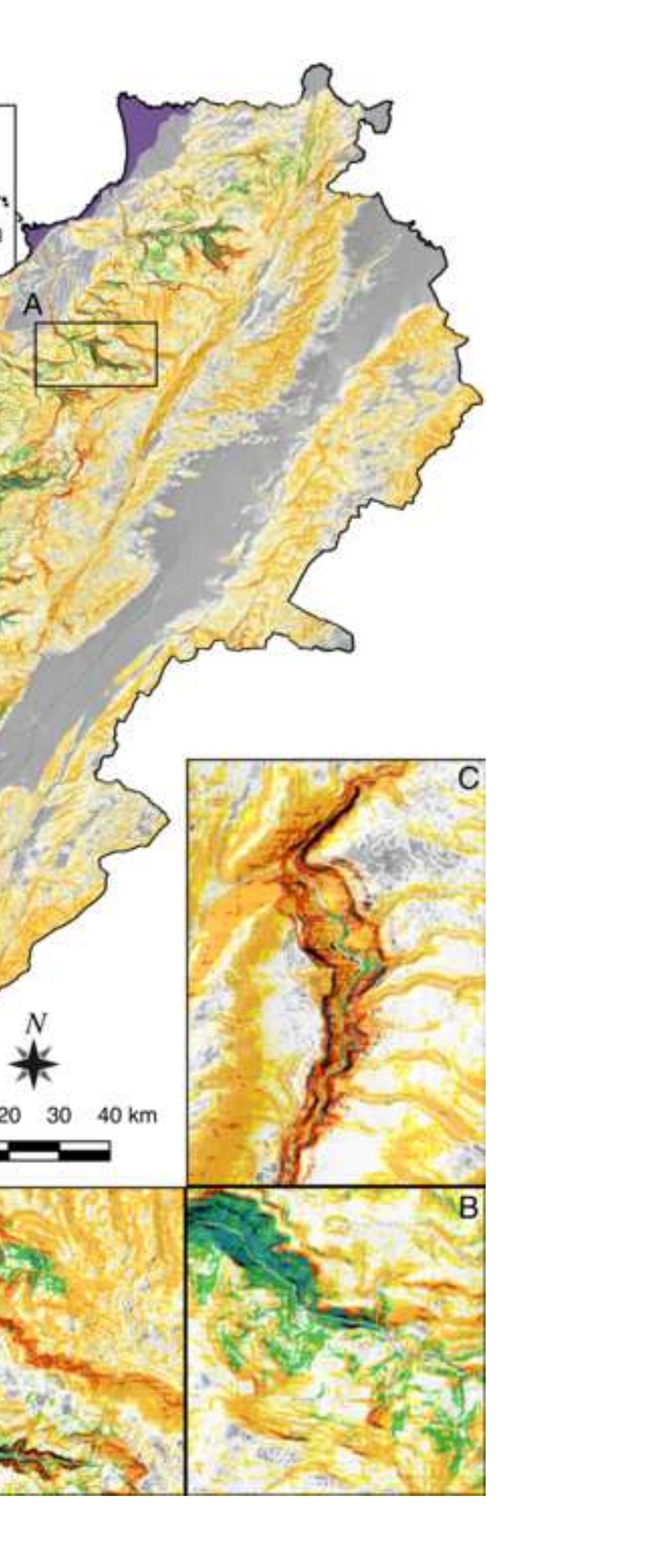




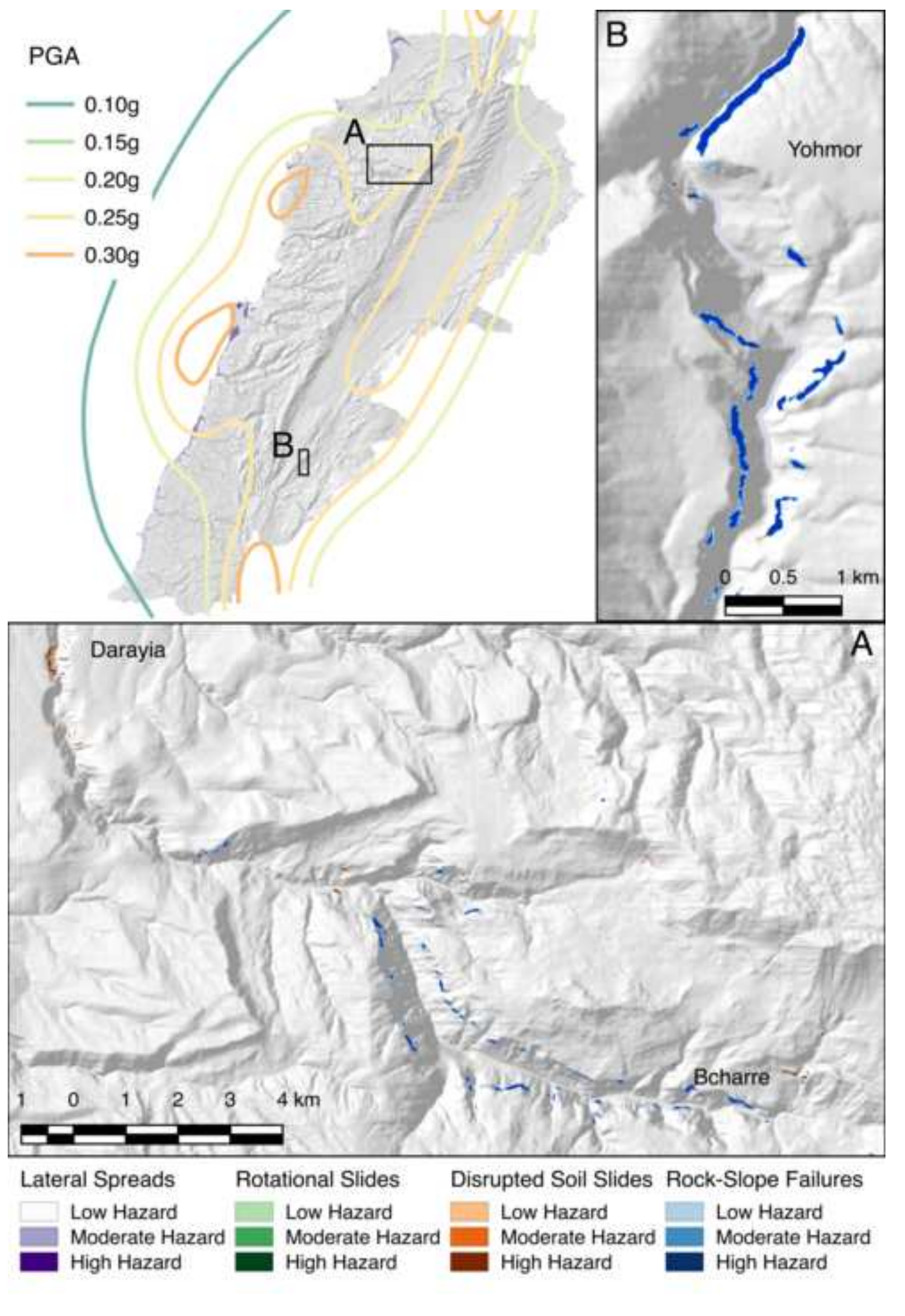

Figure 6 


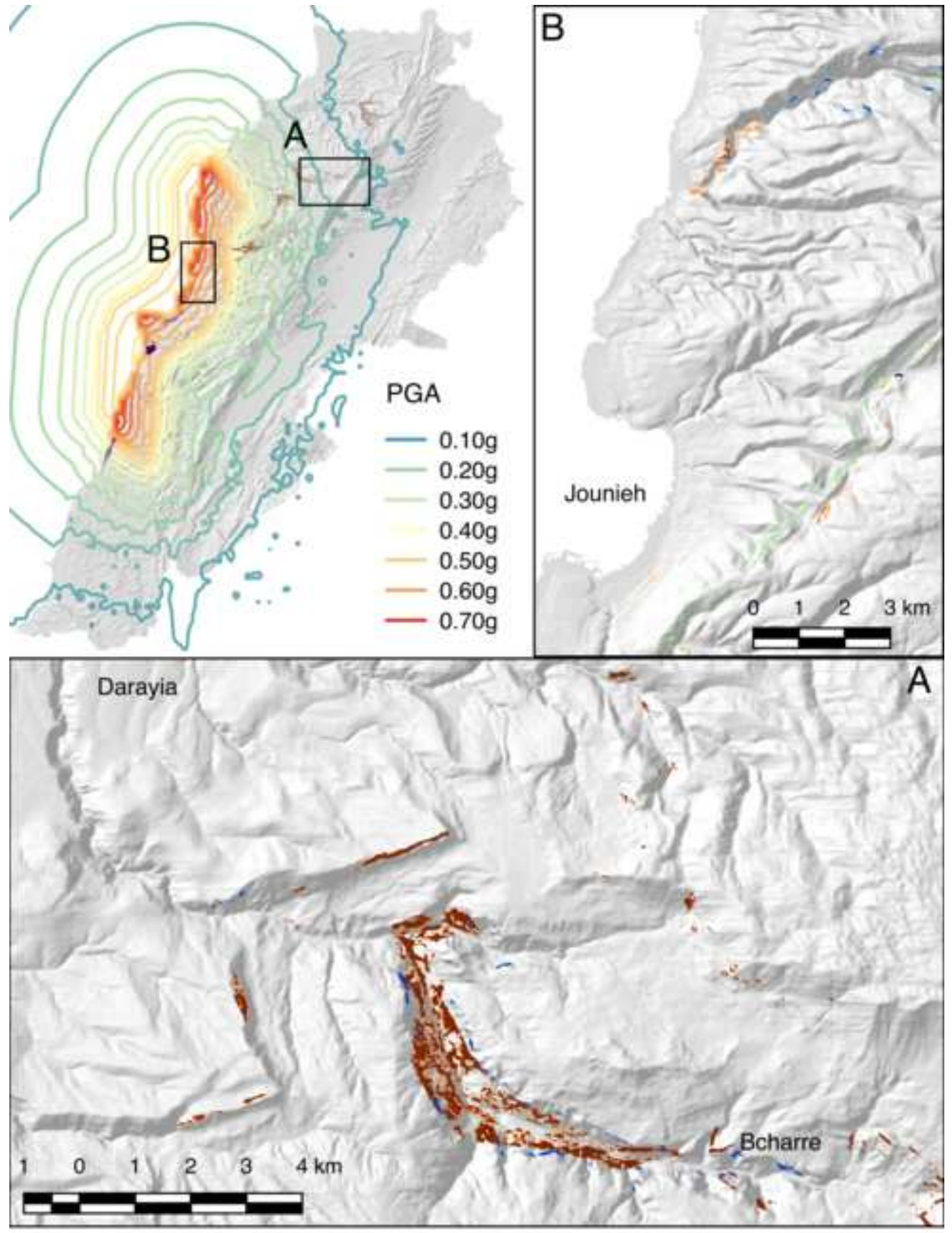

Lateral Spreads Rotational Slides Disrupted Soil Slides Rock-Slope Failures

Low Hazard

Moderate Hazard

High Hazard
Low Hazard

Moderate Hazard

High Hazard

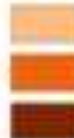

Low Hazard

Moderate Hazard

High Hazard
Low Hazard

Moderate Hazard

High Hazard 


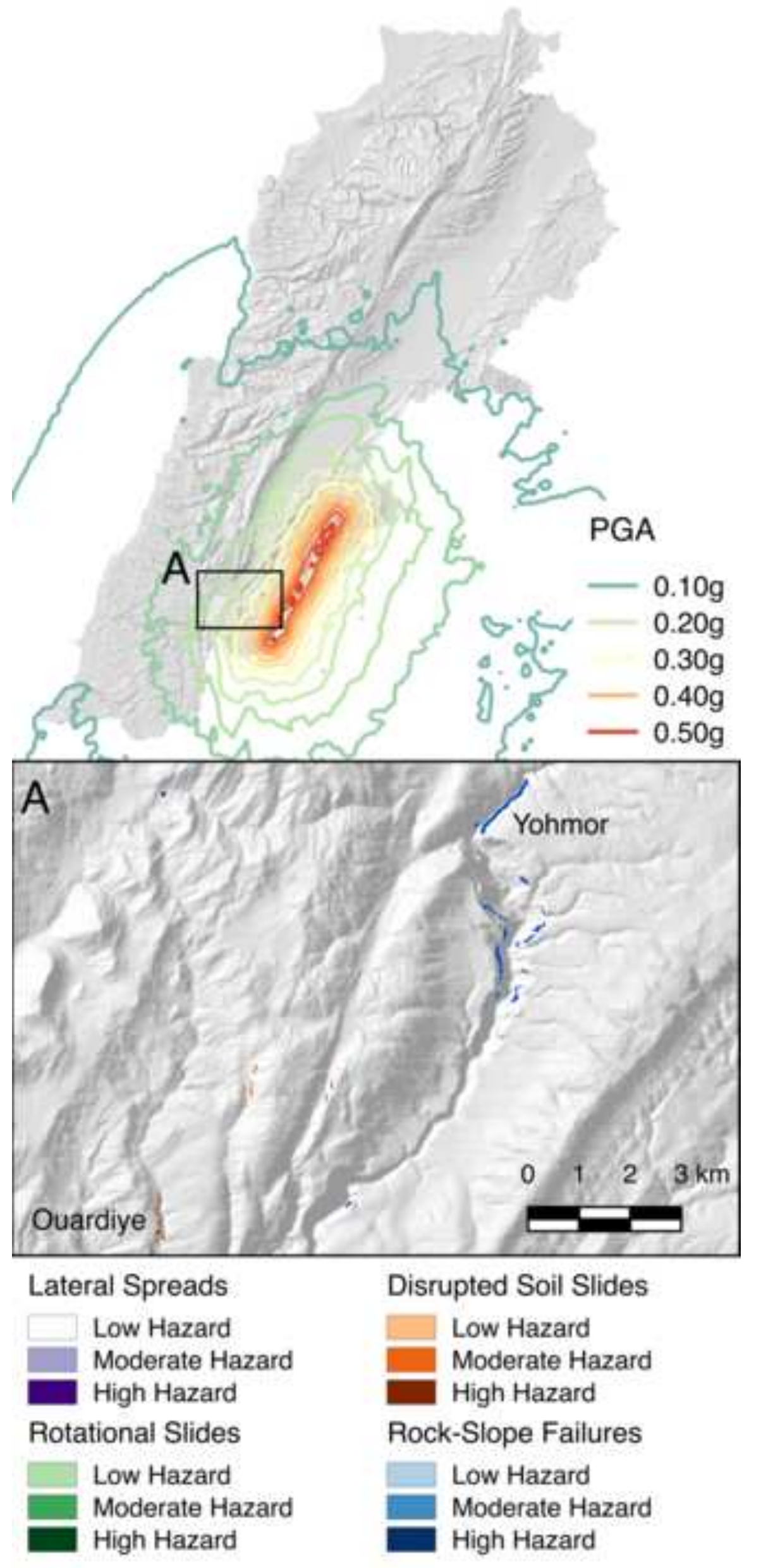




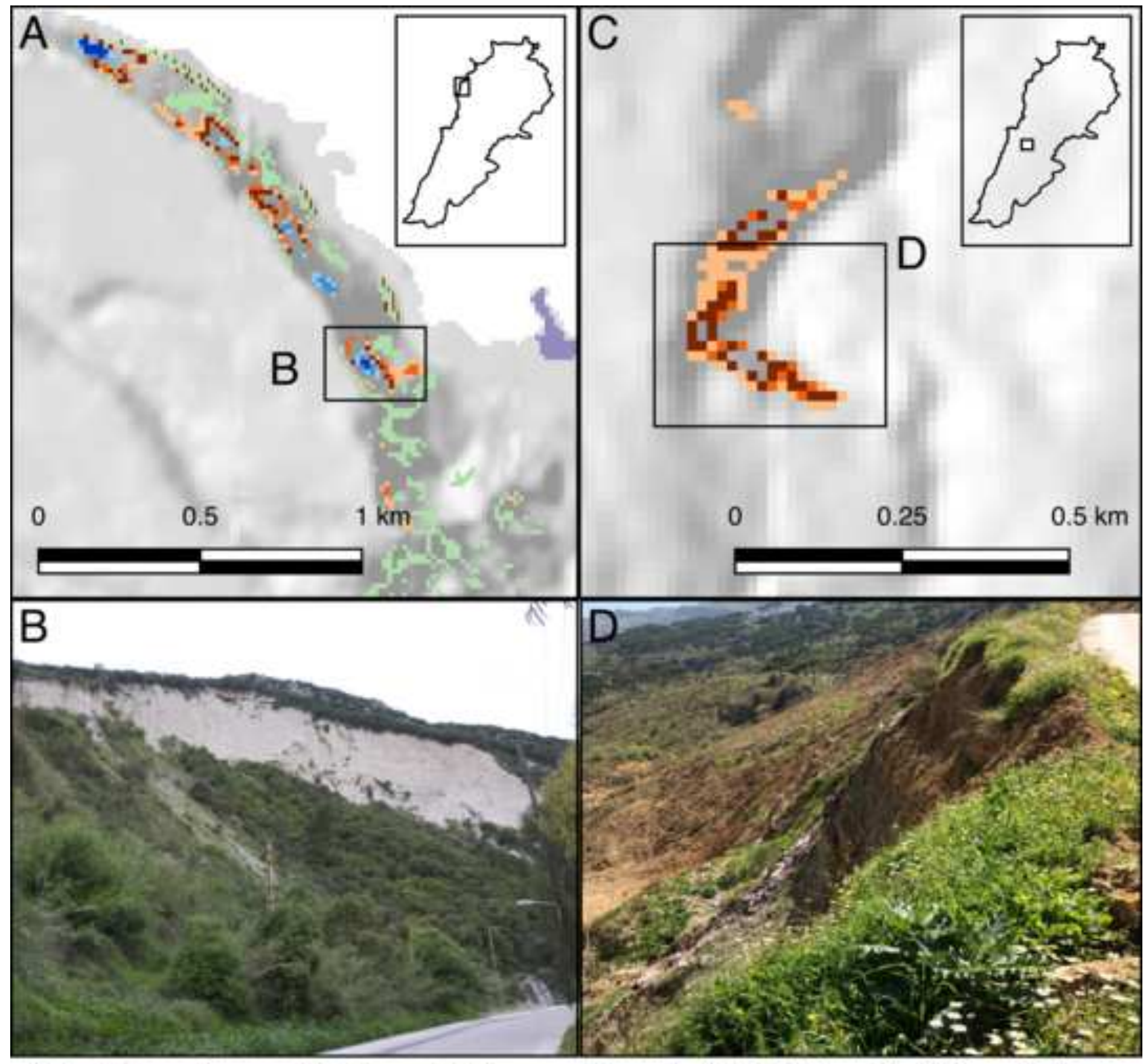

Lateral Spreads

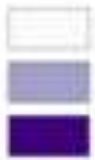

Low Hazard

Moderate Hazard

High Hazard
Rotational Slides

Low Hazard

Moderate Hazard

High Hazard
Disrupted Soil Slides Rock-Slope Failures

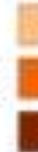

Low Hazard

Moderate Hazard

High Hazard
Low Hazard

Moderate Hazard

High Hazard 

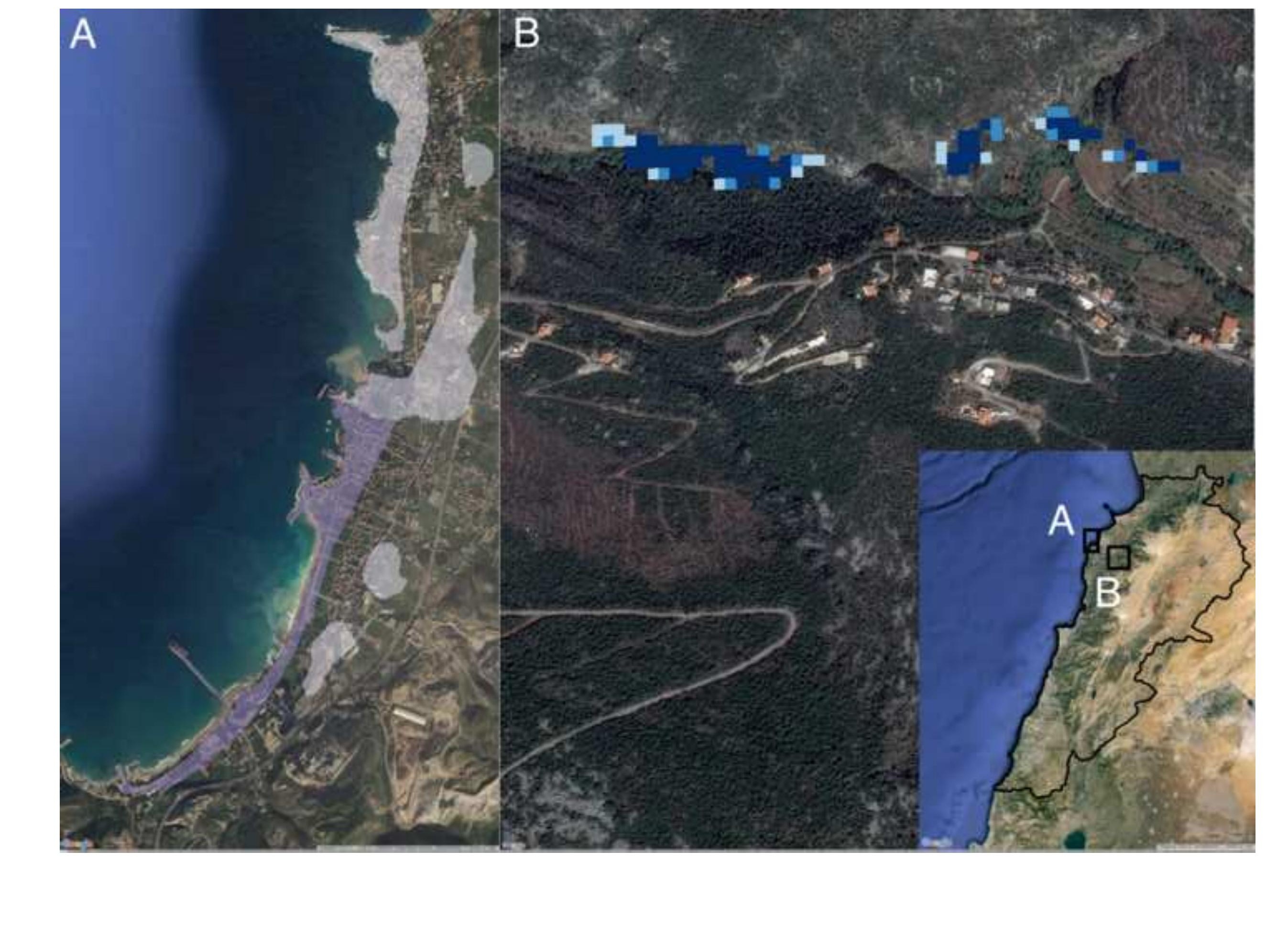

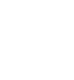

Figure

列
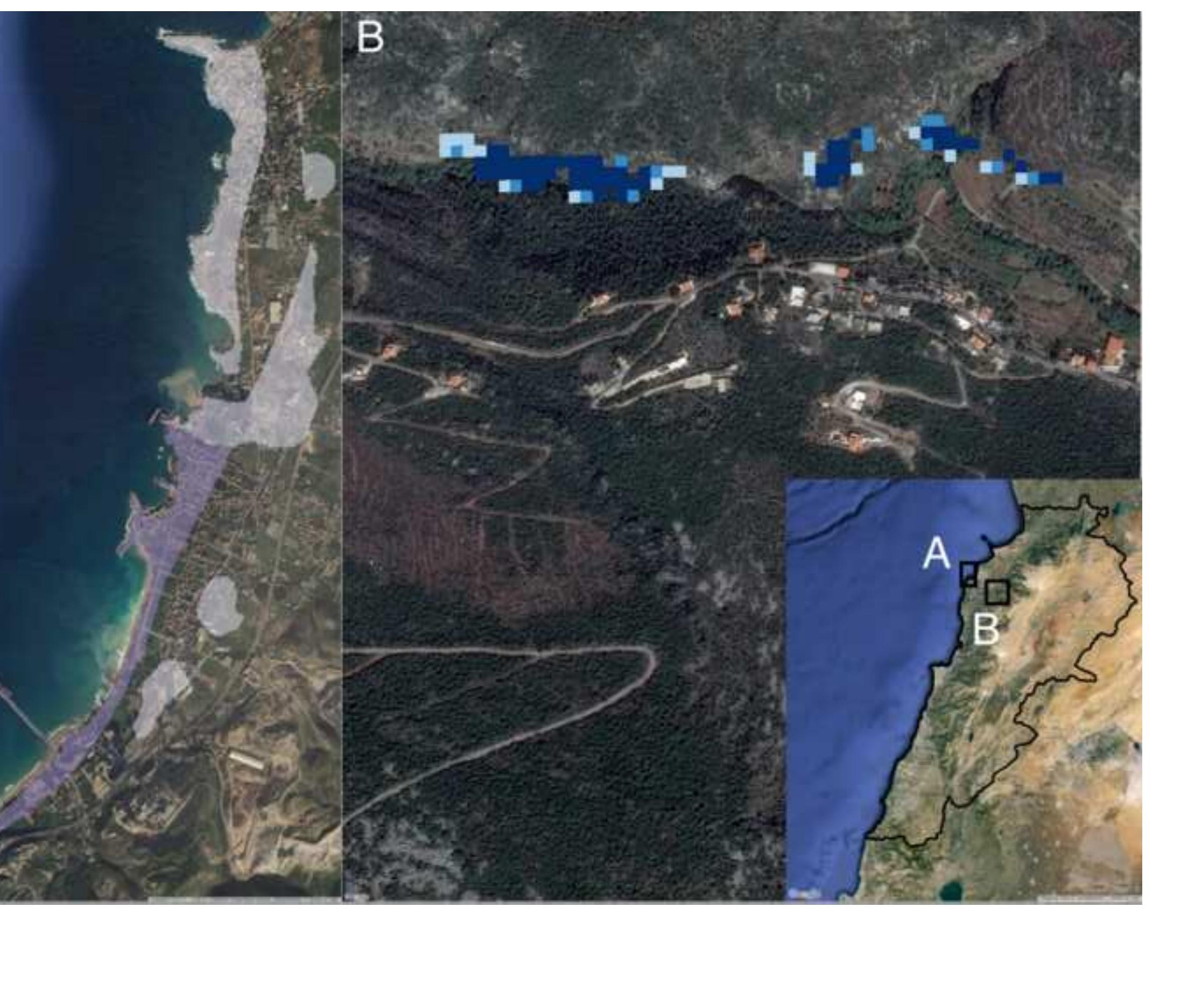


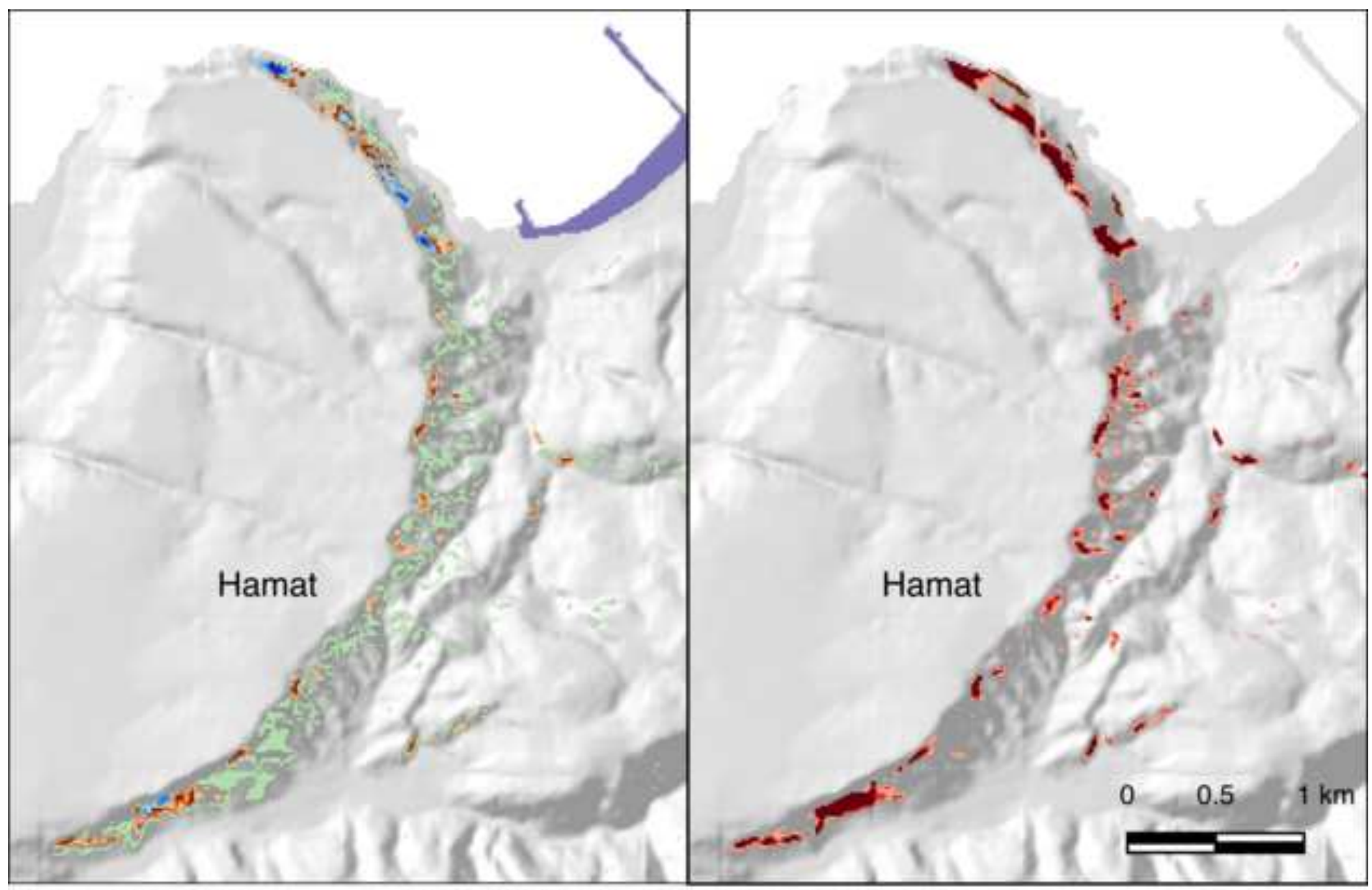

Rock-Slope Failures

Low Hazard

- Moderate Hazard

- High Hazard

Rotational Slides

Low Hazard

Moderate Hazard

High Hazard
Disrupted Soil Slides

III Low Hazard

Eoderate Hazard

High Hazard Lateral Spreads

Low Hazard

Moderate Hazard

- High Hazard
Infinite Slope Analysis

Low Hazard

II Moderate Hazard

- High Hazard 


\section{$1 \quad$ List of Figures}

2 Fig. 1. Geometry used for each mode of failure A. Rock Slope Failures, B. Disrupted Soil Slides,

3 C. Coherent Soil Failures, D. Lateral Spreads

4

5 Fig. 2 Examples of the four modes of landsliding considered in this study. (A) Rock-Slope

6 Failure (B) Disrupted Soil Slide (C) Coherent Rotational Slide, and (D) Lateral Spread. Photos

7 by Joseph Wartman and Scott Deaton following the 2011 Tohoku, Japan (A - C) and 2003

8 Colima, Mexico (D) earthquakes.

10 Fig. 3 Normalized Difference Vegetation Index percentiles prior to the 1994 Northridge,

11 California Earthquake. Blue polygons represent mapped landslides (Harp and Jibson, 1996).

13 Fig. 4. Major geologic units and faults (bold) of Lebanon and locations referenced in this work.

14 Mount Lebanon Range (1) and its foothills are bound by the Yammouneh fault to the East,

15 Mount Lebanon Thrust (MLT) fault to the North, and the Roum fault to the South. The Bekaa

16 Valley (2) divides the high Mount Lebanon Range from the lower Anti-Lebanon Range (3).

17 Rolling southern alluvial valleys and lowlands (4) extend across Lebanon south of the Roum

18 fault. Geology after Dubertret (1945)

20 Fig. 5. Landslide mode of failure susceptibility zones for Lebanon. (A) Steep cliff-lined valleys

21 of the Mount Lebanon Range. (B) Ain Mouaaffaq region outside of Beirut where highly

22 vegetated river valleys divide the more arid highlands. (C) Yohmor Valley in southeastern 
23 Lebanon where extensive cliffs and talus are indicated as susceptible to rock and disrupted soil

24 slides.

26 Fig. 6. Multimodal landslide hazard output for 475 -year (10\% in 50 years) return period PSHA

27 ground shaking intensities. (A) Incised river valley with rock slope and disrupted soil hazard

28 near Bcharre, and disrupted soil slide hazard in the northeast near Darayia. (B), High rock-slope

29 failure hazard is mapped along the edge of the Litani River canyon near Yohmor, while low

30 levels of lateral spreading hazard are predicted along the river banks.

32 Fig. 7. M7.2 Mount Lebanon Thrust scenario earthquake. (A) Increased disrupted soil and rock

33 slope failure hazard along the steep valleys and cliffs of the Mount Lebanon Range. (B) High

34 coastal peak ground accelerations develop predicted multimodal landsliding hazard in vegetated

35 hillslopes near Jounieh north of Lebanon where PSHA-based hazard is not present.

37 Fig. 8. M6.6 Rachaiya earthquake scenario output. (A) Sparse landslide hazard estimated in the

38 South of Lebanon near Yohmor for both rock slope failures and disrupted sliding.

40 Fig. 9. (A) Multimodal hazard output for a MLT scenario earthquake on the near Hamat. (B)

41 Hillslope near Hamat susceptible to multiple modes of landsliding. (C) 475-year return period

42 PSHA landslide hazard prediction for location near Ain Mouaaffaq and (D) hillslope showing

43 active sliding.

44 
45 Fig. 10. Potential consequences due to lateral spread displacements along the Hamat coastline

46 (A) and rock slope failure runouts above Kfour El Aarbi (B). Base Images from Google Earth ${ }^{\mathrm{TM}}$ 47

48 Fig. 11. Comparison of multimodal analyses results (A) with single mode infinite-slope analysis

49 (B) in the vicinity of Hamat. 